Journal of Educational

and Psychological Sciences

Volume (5), Issue (39): 30 Oct 2021

P: 175 - 193

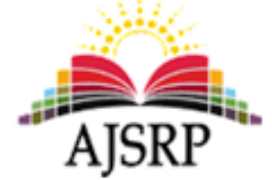

ISSN: 2522-3399

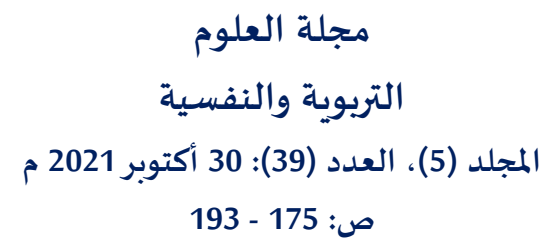

ص: 175 - 193

\title{
The problems of teaching Arabic Rhetoric for the secondary grade students in Jordan from teachers' point of view and its relationship with the gender and teaching experience
}

\section{Fayza Ahmed Saadah}

Ministry of Education || Jordan

\begin{abstract}
The study aimed at identifying the problems of teaching Arabic Rhetoric for the secondary grade students in Jordan from teachers' point of view. using the descriptive analytical curriculum, the sample of the study consisted of (85) secondary classroom teachers of Arabic language in the Directorate of the University directorates to answer the questionnaire, they are the whole study community. And (16) teachers to answer the corresponding questions. Data was analyzed by using (SPSS) to find means, ranks, and the level. And "t" test. The results of the study showed that the level of the rhetoric teaching problems facing the secondary grade students in university directorates from teachers' point of view was moderate as a whole, with a mean of (2.80). Moreover, teaching problems related to the dimensions of the required (textbook) was in the first place, with a high level. Whereas, the level of the rhetoric teaching problems related to (the teacher dimension) was low with the lowest means. This study also shows that There were no significant statistical differences due to gender and teaching experience meanwhile the results showed no statistically significant differences for the interaction between gender. And accordingly, a set of recommendations and suggestions were presented to solve the problem of rhetoric teaching to the secondary students and support teaching it.
\end{abstract}

Keywords: Problems, teaching, rhetoric, the secondary grade students, Jordan, teaching experience.

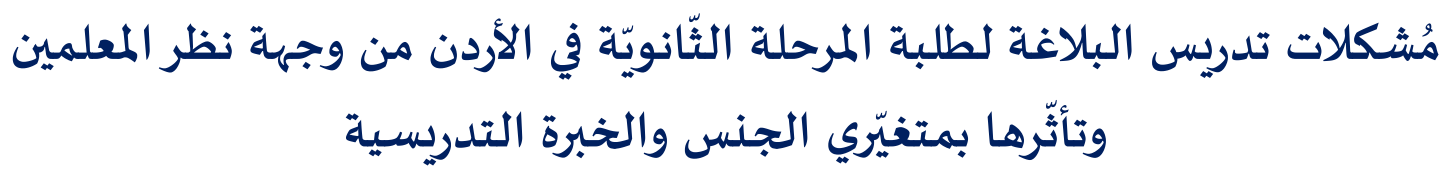

\author{
فايزة أحمد سعادة \\ وزارة التربية والتعليم || الأردن
}

\begin{abstract}
المستخلص: هدفت هذه الدّراسة إلى التعرّف على مشكلات تدريس البلاغة لطلبة المرحلة الثّانويّة في الأردن من وجهة نظر المعلمين.

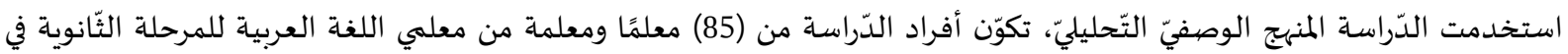

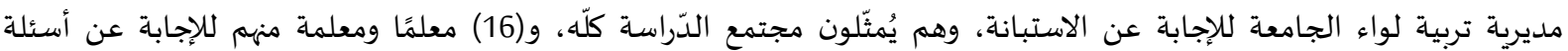

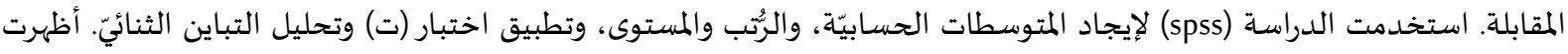

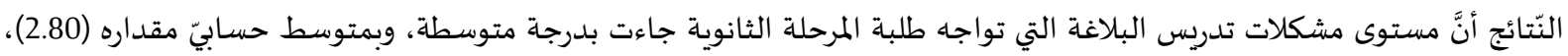

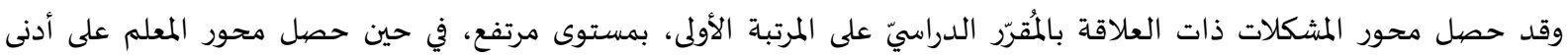

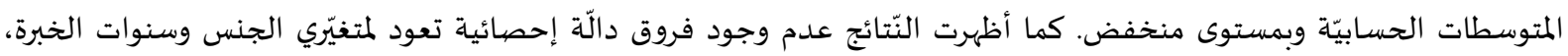
كما لا توجد فروق دالة إحصائية تُعزى للتفاعل بين متغيري الجنس والخبرة التدريسية، وفي ضوهوء النتائج تمّ تقديم جُملةٍ من التّوصيات والمُقترحات لتجاوزِ مشكلات تدريس البلاغة لطلبة المرحلة الثّانويّة وتعزيز تدريسها.
\end{abstract}


غدا الاهتمام بتعليم اللغة العربية مطلب وضرورة، وأصبحت معالجة مشكلاته محور اهتمام الباحثين

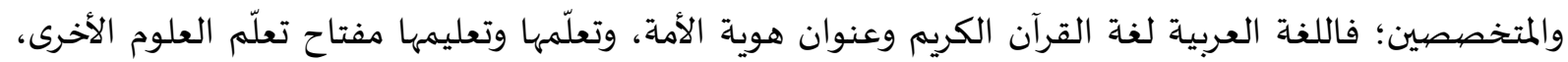

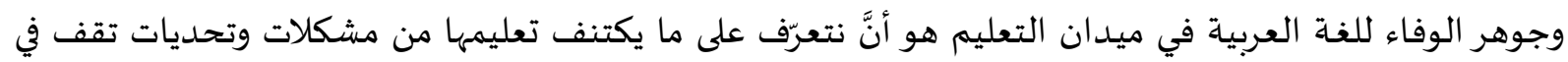

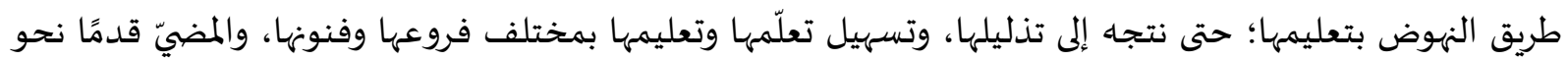

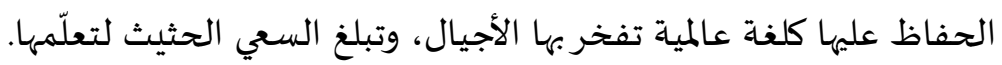

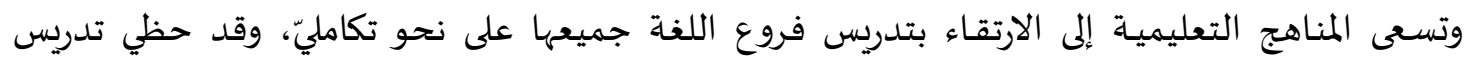

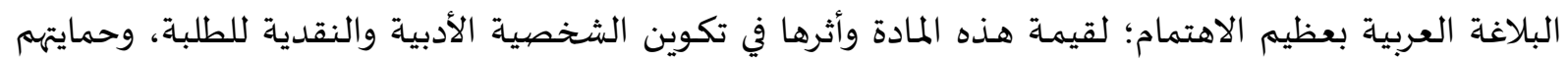

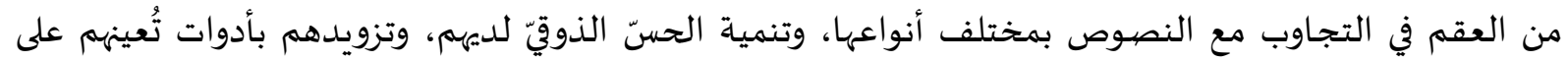

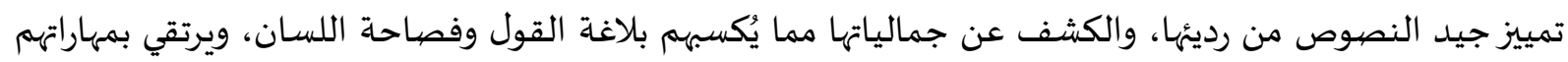
اللغوية جميعها بما يكفل امتلاك سبل التواصل السليم، ويرتقي بمهارات التحليل والتفسير لديهم وصهولاً إلى الإبداع (الدليمي، والوائلي، 2003).

مشكلة الدّراسة وأسئلتها: تشير كثيرٌ من الدراسات إلى أهمية تدريس البلاغة في المراحل المختلفة باعتبارها أوعية معرفية للمعاني

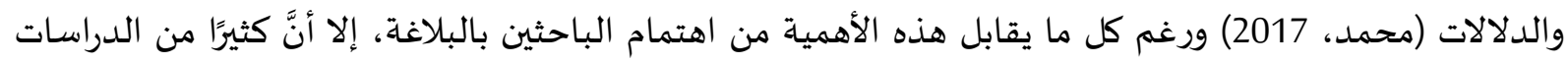

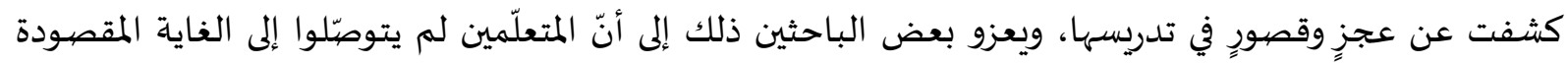

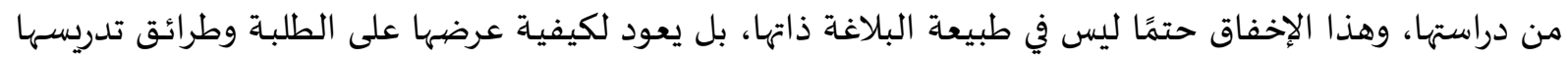

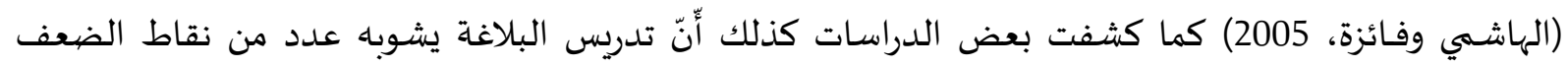

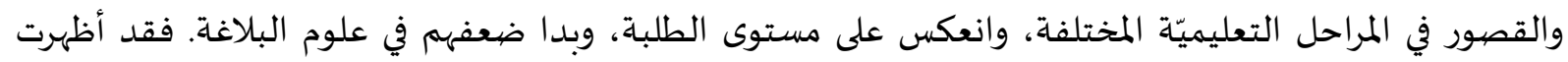

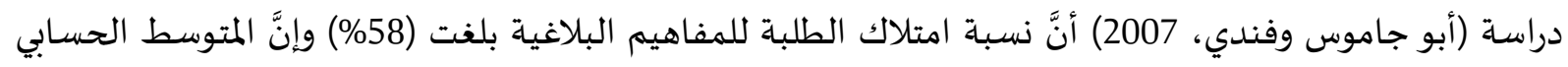

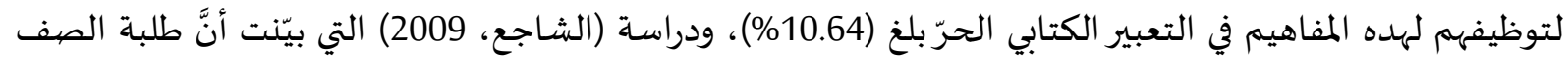

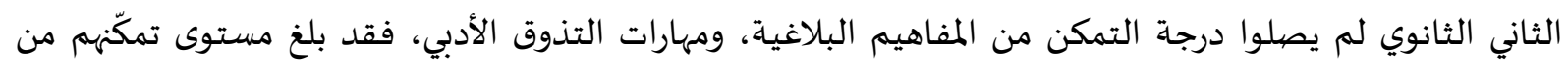

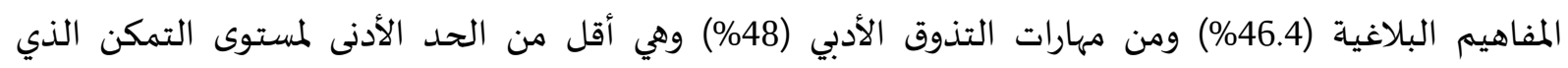

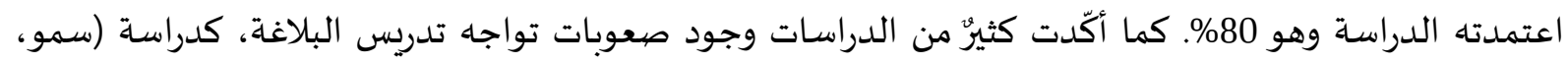

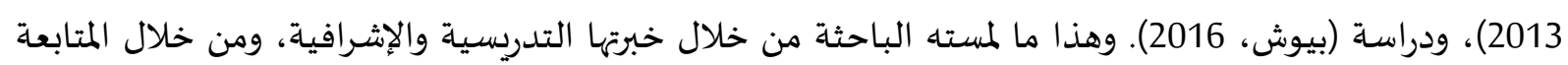

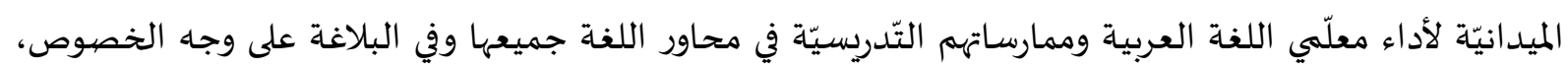
ومن خلال أداء الطّلبة في الاختبارات المدرسيّة أو الوطنيّة وتحليل نتائجهه. من هنا، كانت هذه الدراسة لمحاولة الوقوف على مشكلات تدريس البلاغة لطلبة المرحلة الثانويّة في الأردن

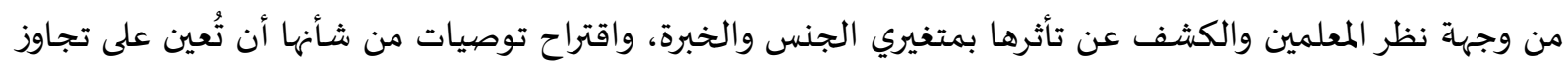
هذه المشكلات. وبالتّحديد سَعت هذه الدّراسة إلى الإجابة عن السؤال الرئيس الآئي:

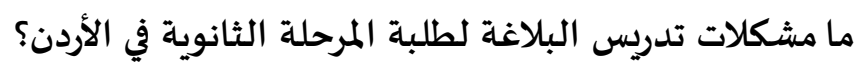

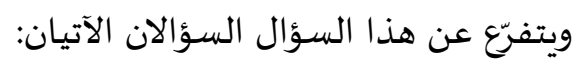

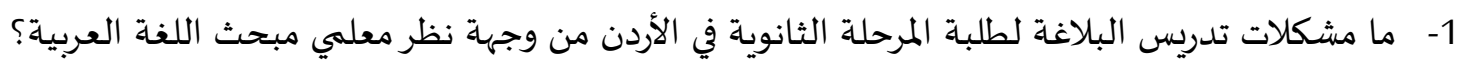


2- هل تختلف مشكلات تدريس البلاغة للمرحلة الثانوية باختلاف الجنس وسنوات الخبرة والتفاعل بينهما؟

افتراضيات الدّراسـة.

1. الظروف العامّة للمدارس كالبيئة الصفيّة وأعداد الطّلبة في الشُعب مُتشابهة.

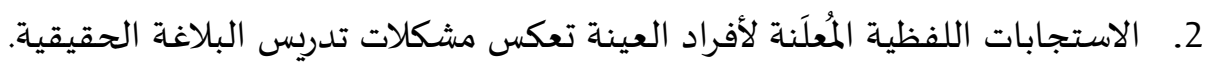

$$
\text { أهداف الدراسـة. }
$$

تهدف هذه الدّراسة إلى ما يأتي:

1. التعرّف على مشكلات تدريس البلاغة لطلبة المرحلة الثانوية في الأردن.

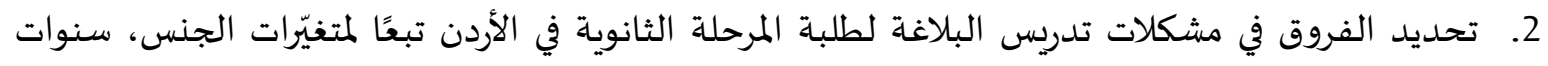

$$
\text { الخبرة والتفاعل بين الجنس وسنوات الخبرة. }
$$

أهميّة الدّراسـة.

أولاً: الأهميّة النظريّة: تُجسيّد أسئلة الدراسة أهميّتها النظرية وذلك بالإجابة عن أسئلتها.

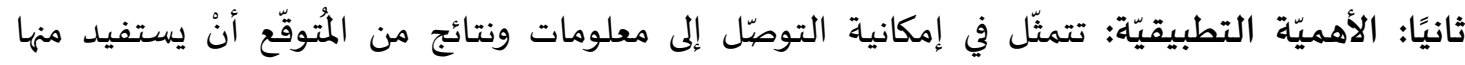

المعنيّون في مجال التّبية والتّعليم ممثلةً في: تانيّا: - إدارة المناهج / قسم اللغة العربية: بإعادة النظرفي النتاجات العامة لمحور البلاغة، وفي طبيعة المحتوى وطريقة عرض المادة وطبيعة الشواهد، والتدرببات العملية على الموضيوعات البلاغية. - المشرفين التربويين: بالوقوف على مشكلات تدريس البلاغة وعدّها من حاجات المعلمين التي تتطلّب تكثيف واتل

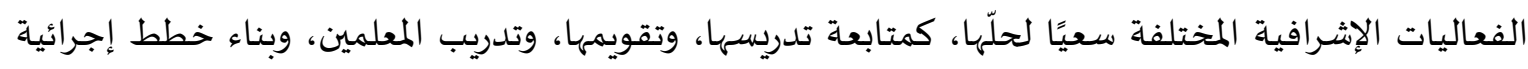

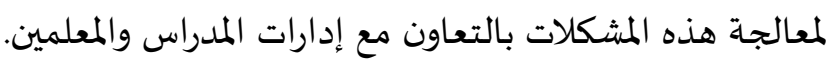

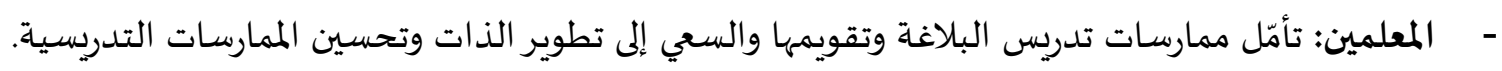

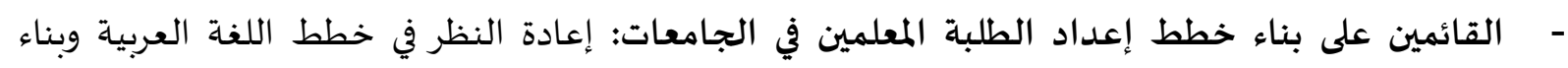
الخطط في ضوء المشكلات التي تكشف عنها الدّراسات والأبحاث.

حدود الدّراسـة

تتناول هذه الدراسة مشكلات تدريس البلاغة لطلبة المرحلة الثانوية في الأردن؛ ولذا فإنهّا تتحدّد بما يلي: الحدود الموضوعية: مشكلات تدريس البلاغة لطلبة المرحلة الثانوية في الأردن.

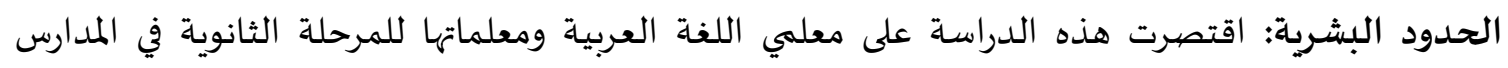

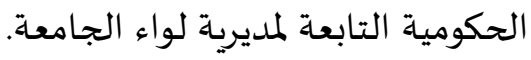
الحدود المكانية: المدارس الحكومية التابعة لمديرية التربية والتعليم للواء الجامعة. الحدود الزمانية: الفصل الدراسيّ الأول من العام الدراسيّ (2019/ 2020).

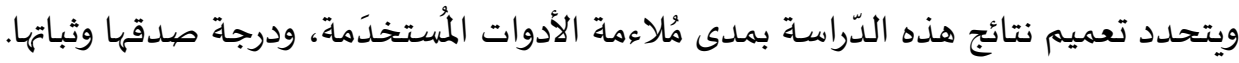


التعريفات الاصطلاحية والإجرائية:

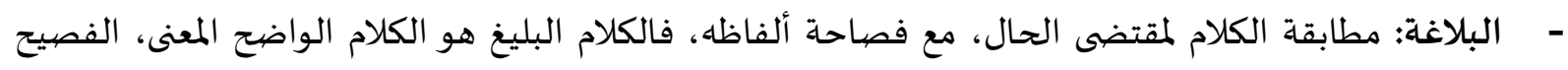

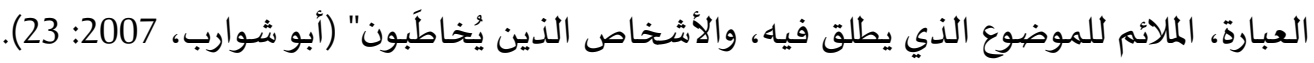

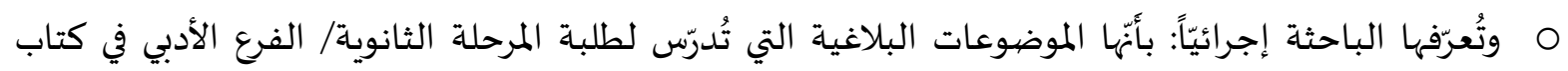

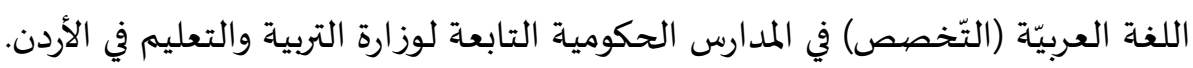

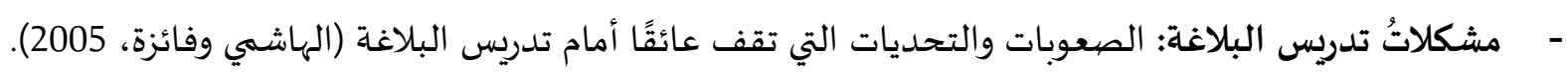

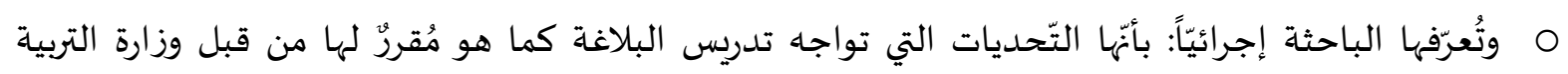

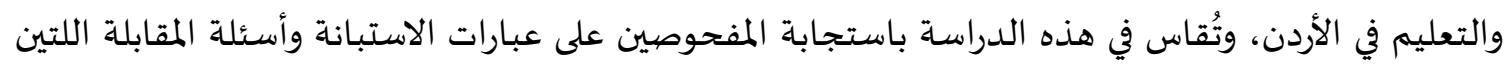
تقيسان مشكلات تدريس البلاغة في المدارس الثانوية في الأردن.

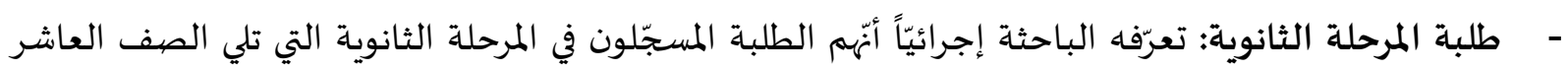
الأسـاسي وتمتد من عمر (16 - 18) وتتكوّن من الصفين (الحادي عشر والثاني عشر الأدبي) للعام الدراسي 2019

.2020 /

- معلمو اللغة العربية: تعرّفه الباحثة إجرائيّاً أنهّم المعلمون والمعلمات الذين يُدرّسون مبحث اللغة العربية

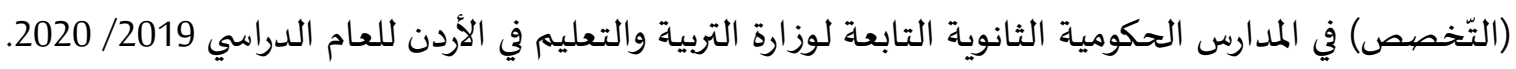

$$
\text { 2- الأدب النظريّ الدراسـات السابقة. }
$$

تعريف البلاغة

البلاغة في اللغة الوصول والانتهاء، يُقال: بلغَ فلانٌ مراده إذا وصل إليه (ابن منظور، 2005). وتقع في

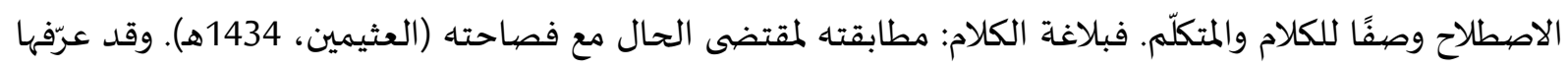

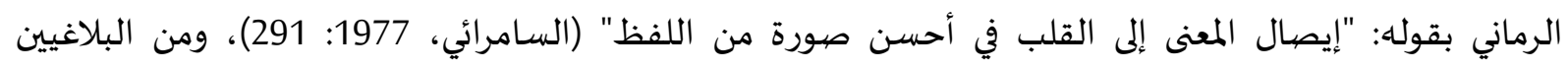

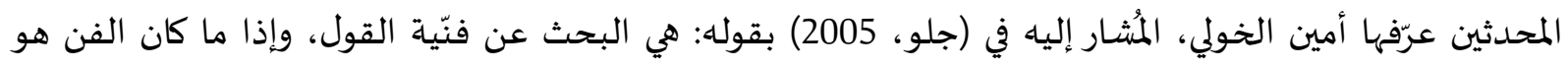

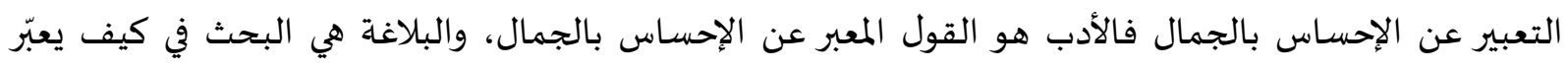
القول عن هذا الإحساس.

أقسام علم البلاغة

يُطلق اسم أقسام البلاغة في اللغة العربية على علوم البلاغة الثلاثة، وهي:

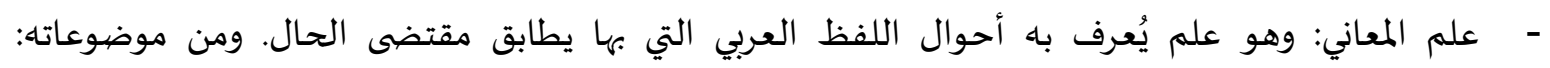

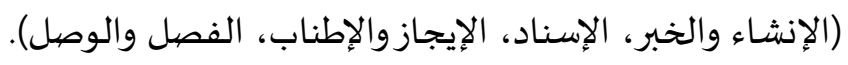

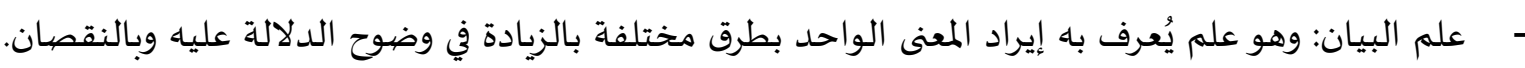
ومن موضوعاته: (التشبيه، والاستعارة، والكناية والإيجاز).

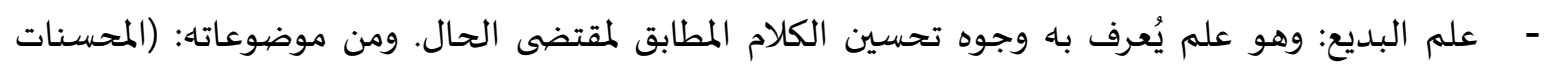

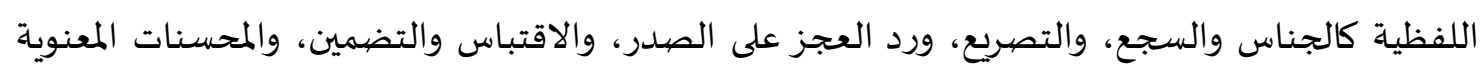

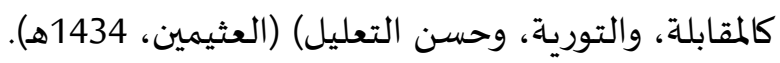




\section{مؤسس علم البلاعة}

بحثَ في البلاغة العربية كثيرٌ من الدراسين العرب، منهم الجاحظ في كتابه البيان والتبيين، وقدامة بن جعفر

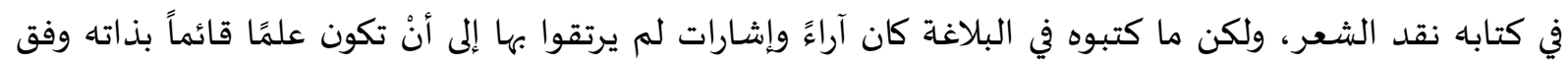

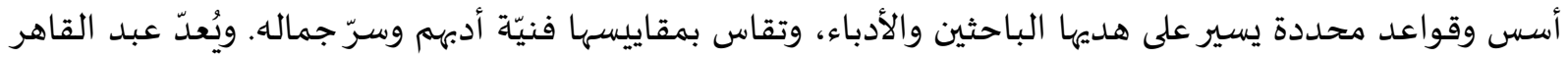

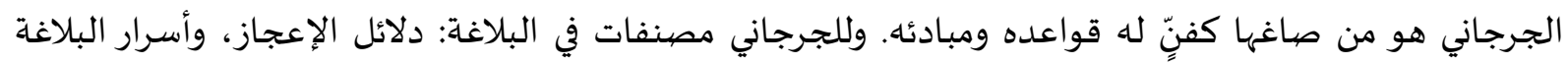

(جلو، 2005؛ حني، 2017).

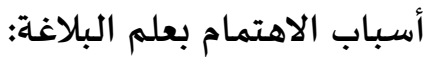

تناول العرب البلاغة بالبحث والدراسة لسببين: أحدهما فنيّ: ففي بادئ الأمر كانت إرشادًا وتعليمًا للذين

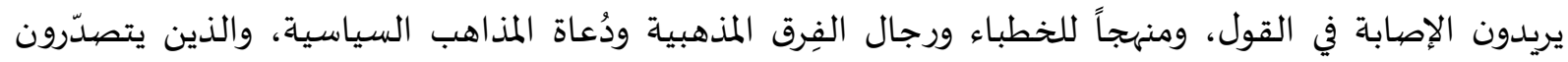
الكلام أمام الجموع. ومن ثم صارت لتمييز جيد الكلام من رديئه، وإظهار مواطن الجمال في الأدب. ثانيهما ديني: فبعد الهد

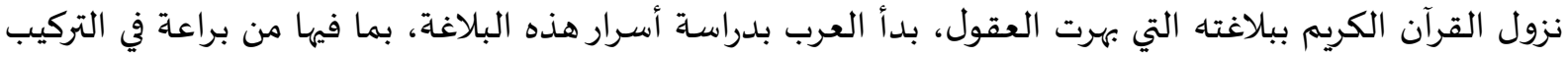

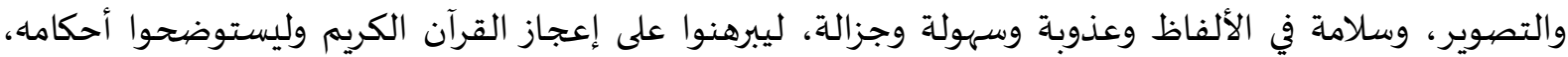

ويتفهّموا معانياء (جلو، 2005).

فوائد تعليم البلاغة العربية: - - فهم ما في القرآن الكريم من معانٍ وأحكام وأخبار وقضيايا، فلا بدّ للناظر في القرآن من الإلمام بقواعد هذا العلم لمعرفة ما يدل عليه التكرار، وما ينطوي عليه الحذف، وغير ذلك مما يتصل بقواعد هذا العلم.

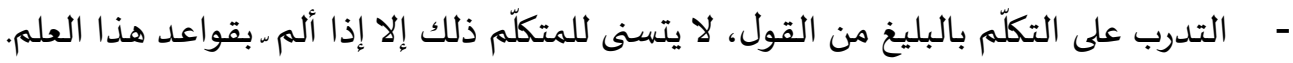

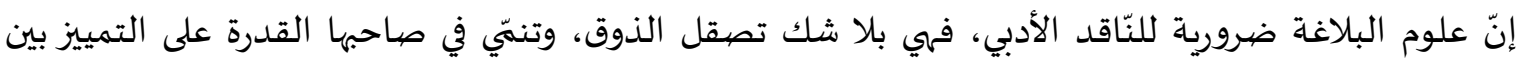
الكلام الجيد والكلام الرديء، فهي تساعد على إدراك الجمال وتذوق الجمال في ألوان الكلام.

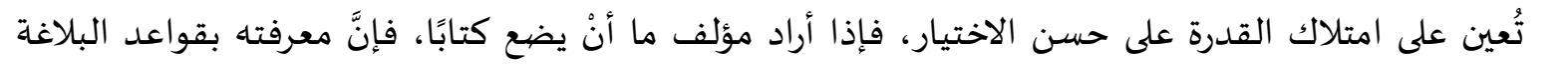
تعينه على الاختيار.

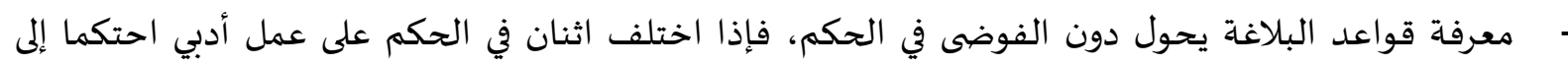
علم البلاغة، وكان في احتكامهما ما يردّ المخطئ عن خطئه.

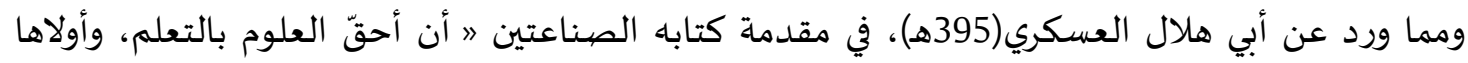
بالتحفظ، بعد المعرفة بالله جل ثناؤه علم البلاغـة، ومعرفة الفصاحة، الذي بهاه يعرف إعجاز كتاب الله تعالى (حني، 2016).

دراسة البلاغة وتعلّمها بين التلقين والإنتاجية:

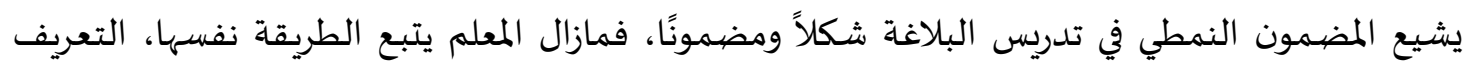

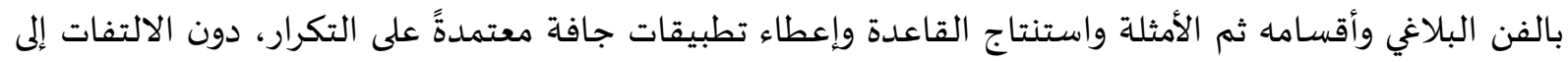
الجوانب التذوقية والإبداعية لدى الطالب وكشف شخصيته، وزادت المشكلة تفاقما لارتباط البلاغة بمقاربة

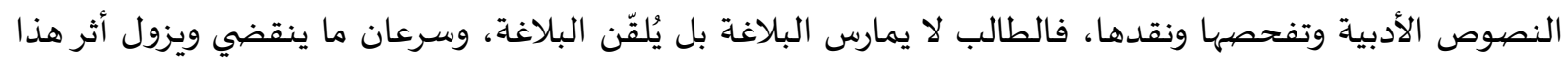

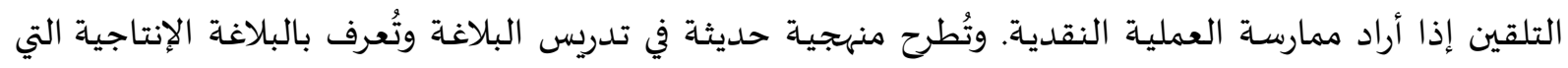

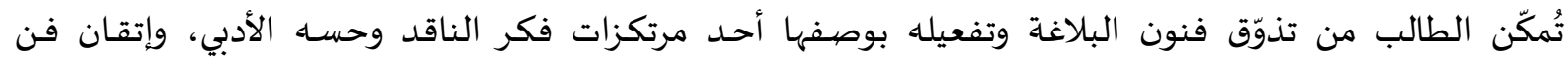


الهندسة البلاغية، ومن ثم إنتاج نصوص أدبية محكمة بليغة في أساليبها، غنية في معانيها. وهذه الطريقة الجديدة

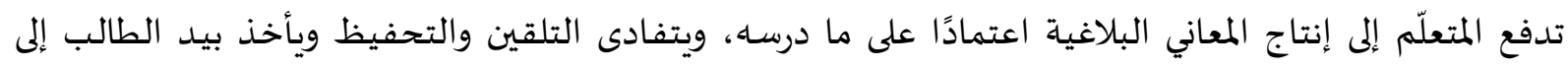

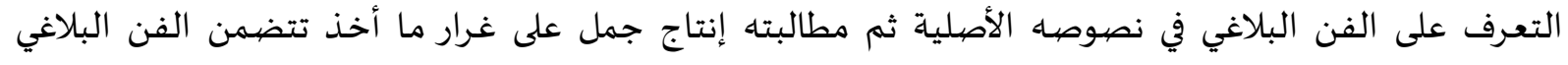

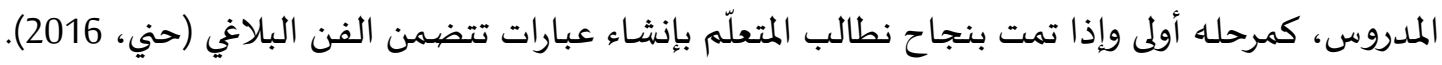

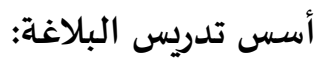

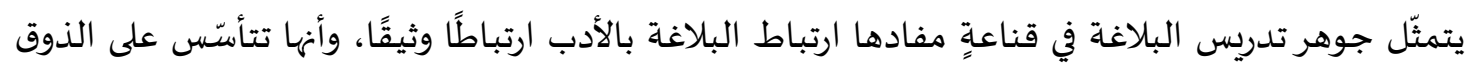

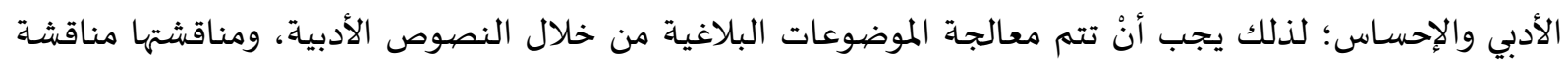

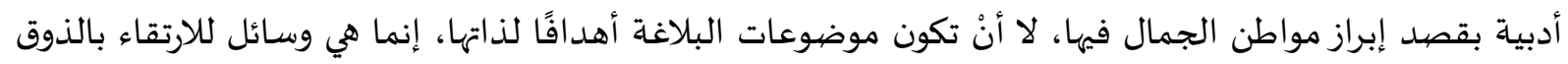

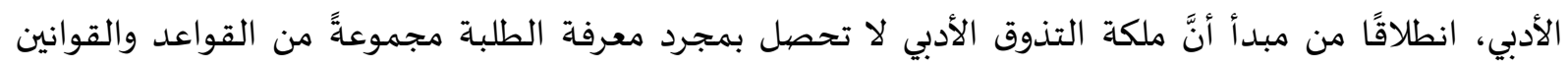

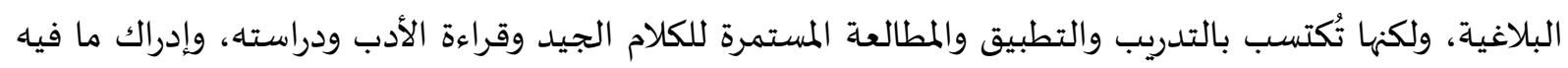

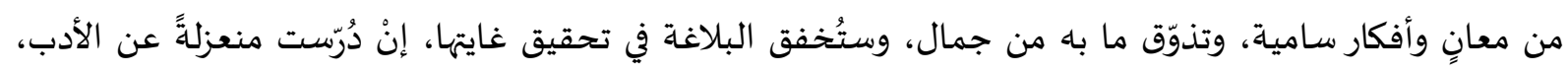

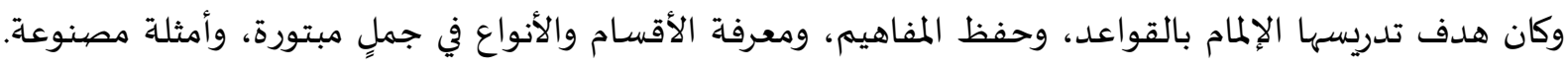

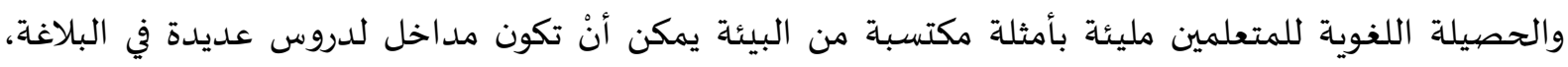

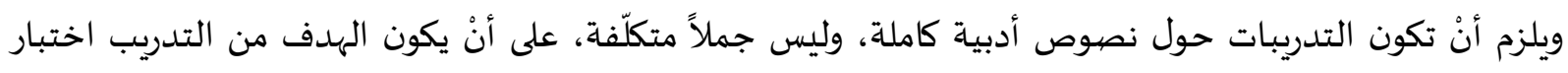

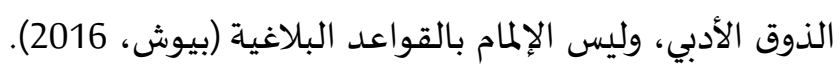

تدريس البلاغة في المناهج الأردنية:

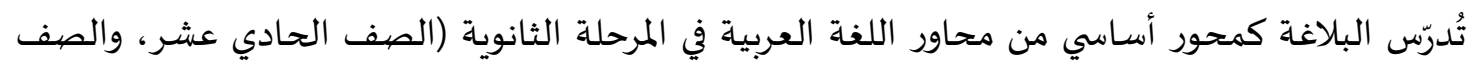

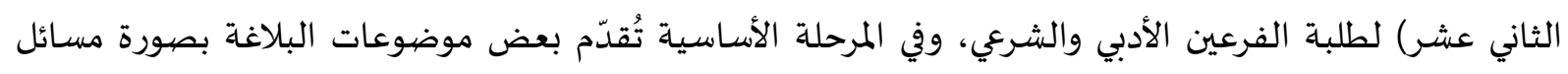

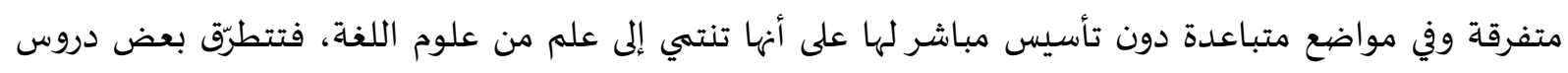

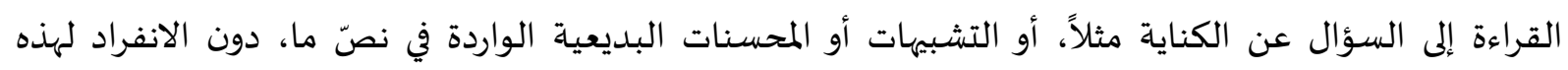

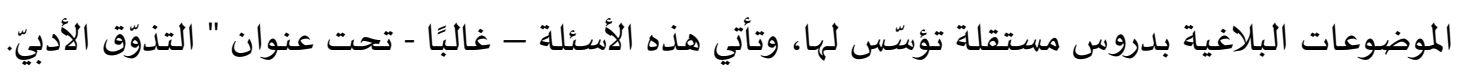

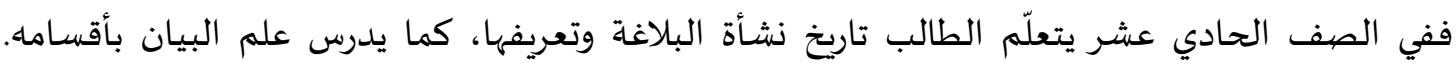
ويدرس في الصف الثاني عشر عِلمي المعاني والبديع ويتضمّن الكتاب مناصفةً البلاغة العربية والنقد الأدبي (وزارة التربية والتعليم، 2013). ووفق وثيقة أسس النجاح والإكمال والرسوب فإنَّ نصيب الحصص لمحور البلاغة العربية والنقد الأدبي هو

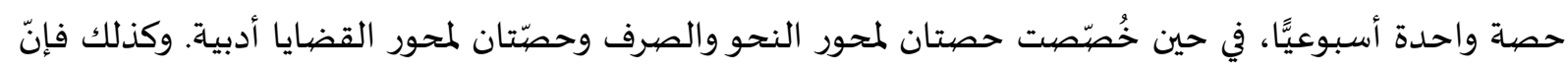

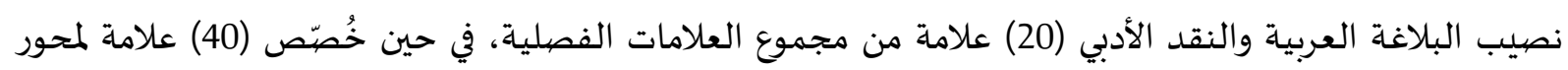

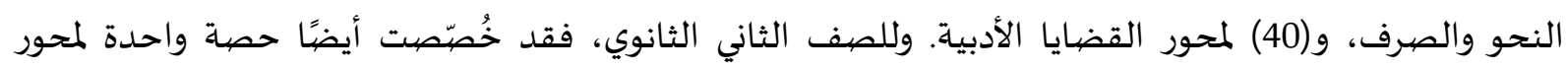

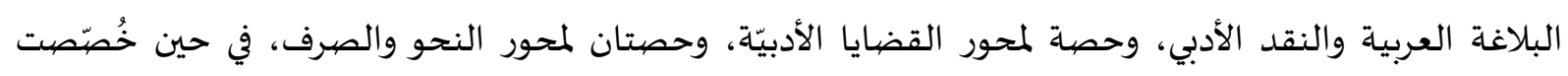

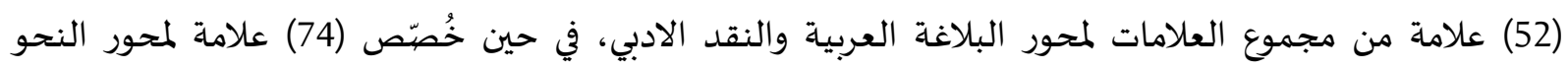
والصرف، و(74) علامة لمحور القضايا الأدبية (وزارة التربية والتعليم، 2020). 
ثانياً- الدراسات السابقة:

- في دراسة حني (2017) التي هدفت إلى الكشف عن تعليميـة البلاغـة العربيـة لمتعلمي اللغـة العربيـة في مـادة

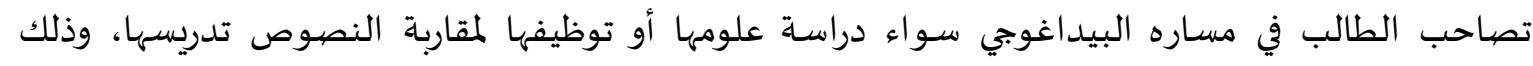
بتفحّص طريقة تدريسها التي قد توصف في بعض الأحيان بالنمطيّة والتّقيّد بالقوالب الجاهزة، ومحاولة

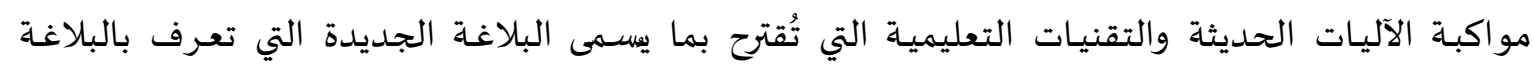

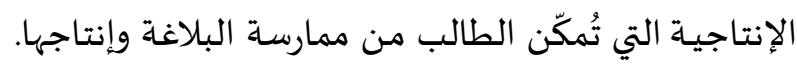

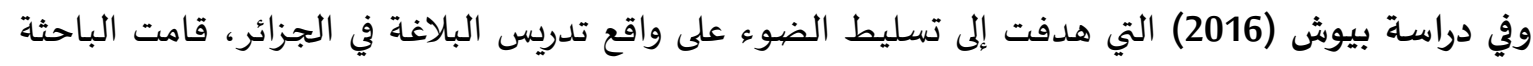
بجولة ميدانية استطلاعية وحضور عدد من حصص البلاغة في مجموعاة من المدارس الثانوية في الجزائر،

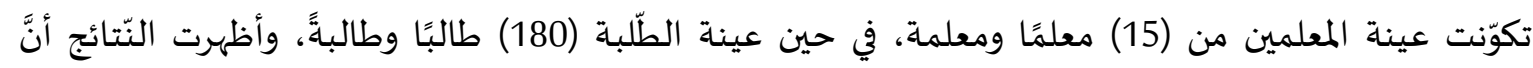

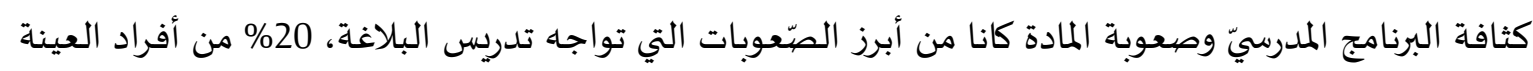

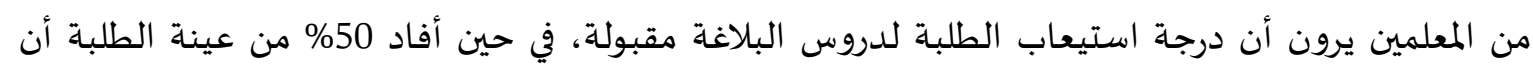
المعلمين لا يلتزمون بالفصحى، و65\% منهم أفادوا أنَّ دروس البلاغة دمُ دملّة.

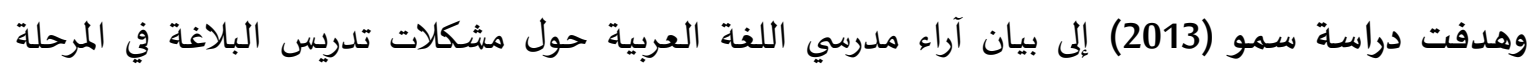

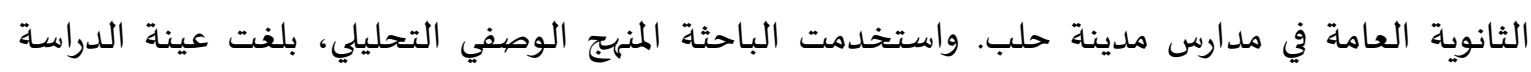
(282)، مدرّسًا ومدرّسة تم اختيارهم بطريقة عشوائية من مدرسي اللغة العربية في المرحلة الثانوية العامة، مدانة

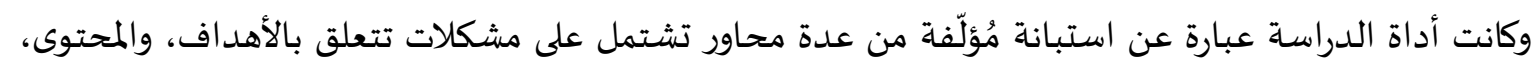

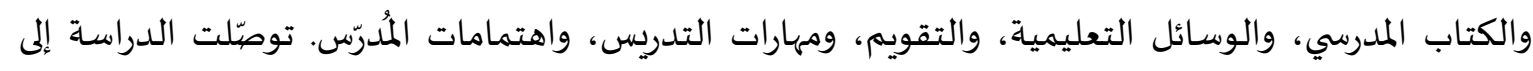

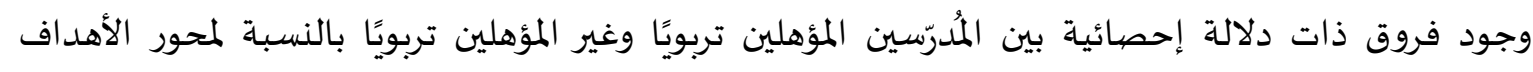

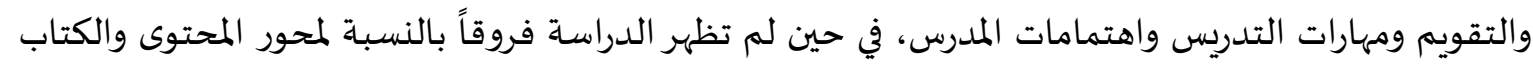

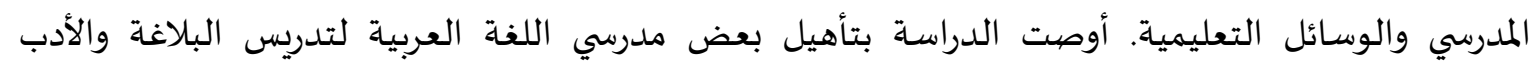

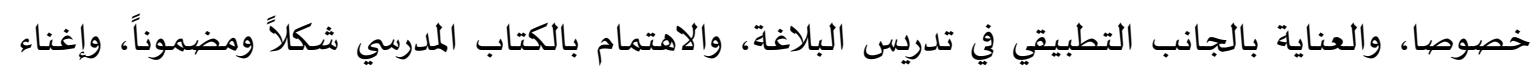
المكتبات بالمراجع الضرورية في مجال الأدب والتدريس. وأجرى الشمّري (2004) دراسة هدفت إلى الكشف عن مشكلات تدريس البلاغة المرتبطة بالأهداف، والمحتوى،

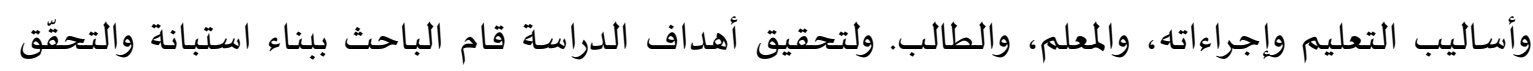

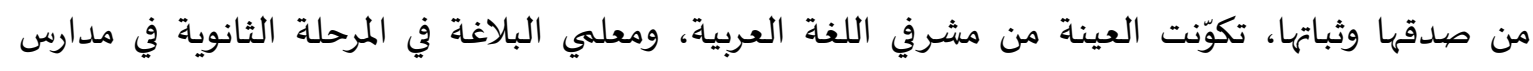

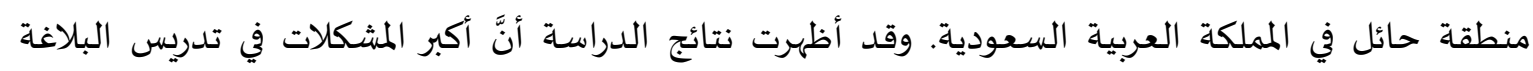

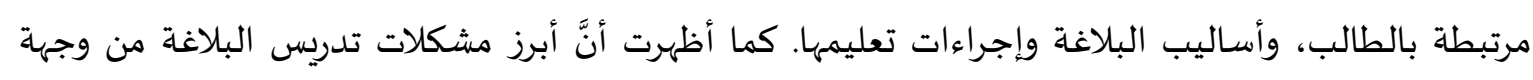

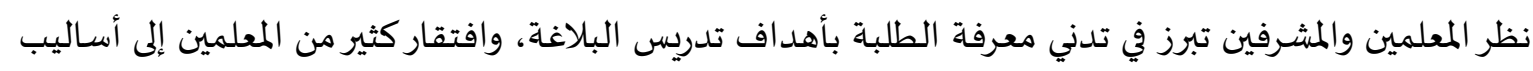

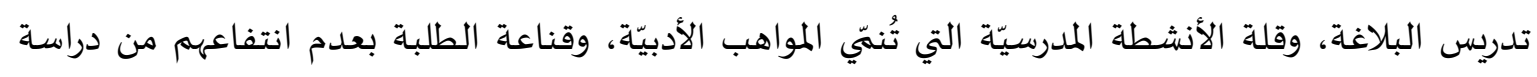
البلاغة في حياتهم اليوميّة. - هدفت دراسة عايش (2003) إلى تحديد صعوبات تعلم البلاغة لدى طلبة قسم اللغة العربية بالجامعة

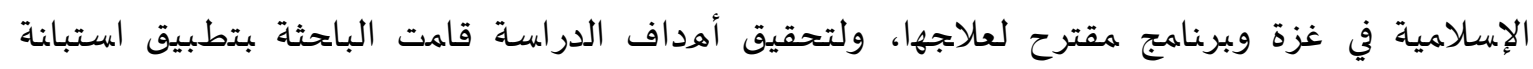

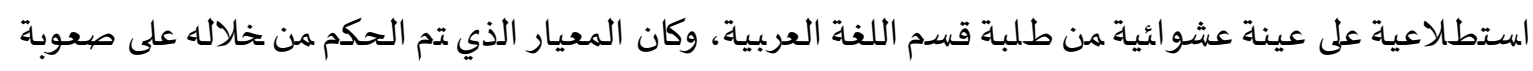

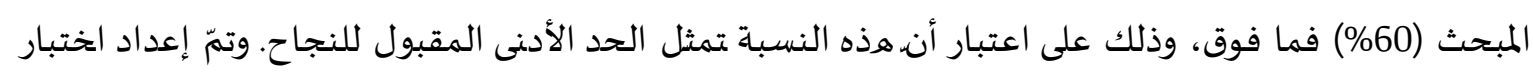

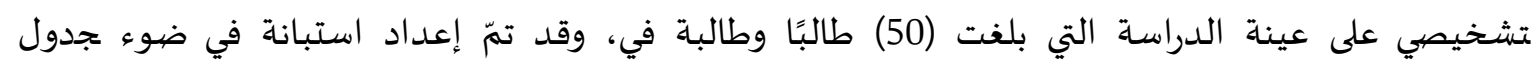


التصنيفات الذي حِدّد من قبل أساتذة البلاغة، وبعد إجراء المعالجات الإحصائية اللازمة، كشفت نتائج

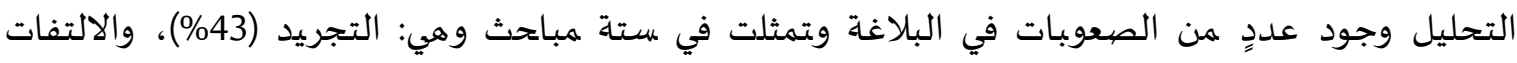

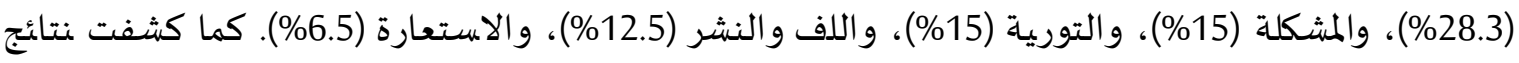

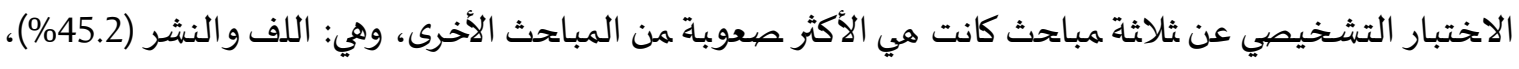

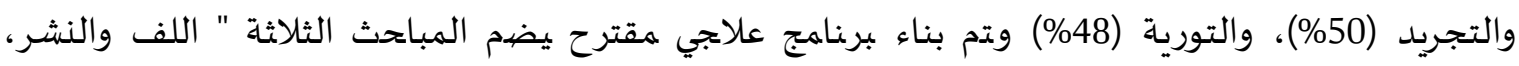

$$
\text { والتجريد، والتورية". }
$$

التعقيب على الدراسات السابقة

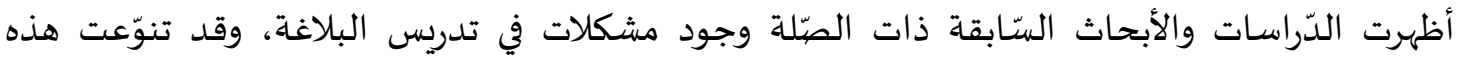

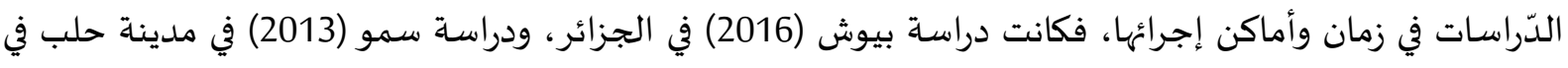

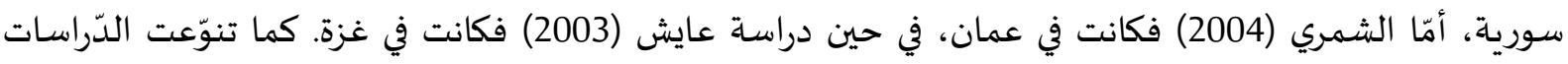

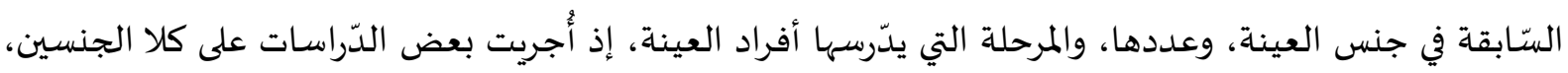

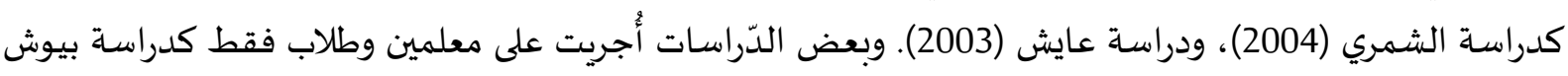

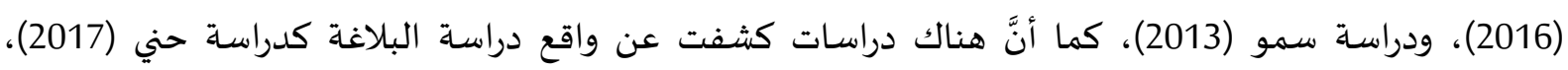

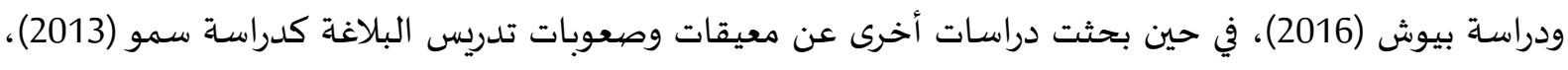

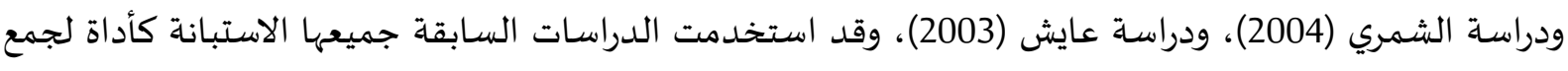

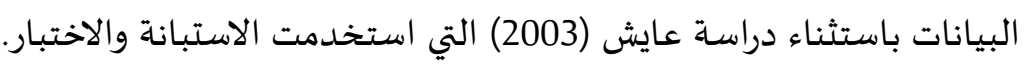

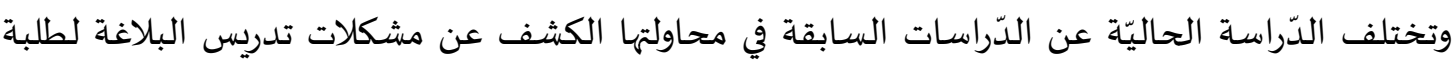

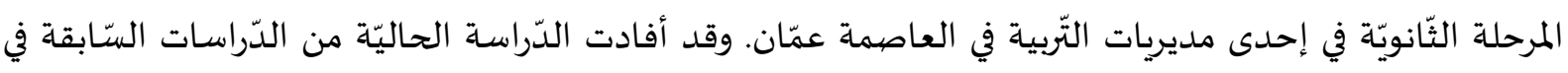

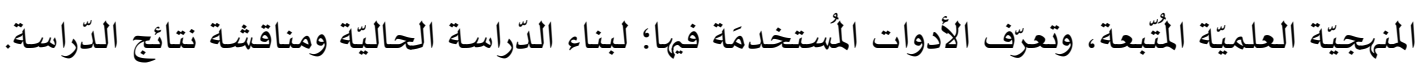

3- منهجيّة الدّراسـة وإجراءاتها.

منهجيّة الدّراسة

استخدمت الباحثة المنهج الوصفي التحليلي، وهو المنهج الذي يدرس ظاهرةً أو حدثًا أو قضية موجودة حاليًا

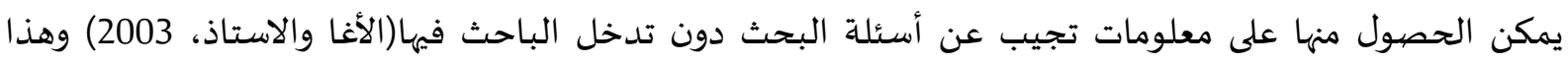

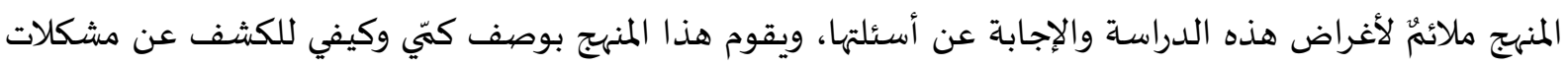

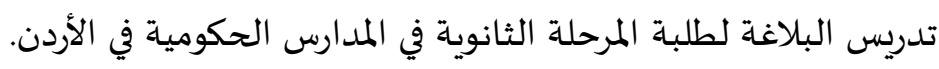

\section{متبتمع الدراسسة:}

تكونن مجتمع الدراسـة من جميع معلمي مبحث اللغة العربية (التخصص) ومعلماته، الذين بيدرسسون المرحلة

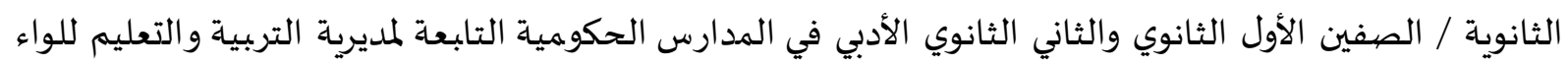
الجامعة للعام الدراسي 2020/2019 والبالغ عددهم (85) معلما ومعلمة.

عينة الدراسـة: - مينا

اختلفت عينة الدراسة وفقًا لاختلاف الأداة البحثية. 
عينة أداة الاستبانة: تككونت عينة الدراسة من جميع معلّمي مبحث اللغة العربية (التّخصص) ومعلماته

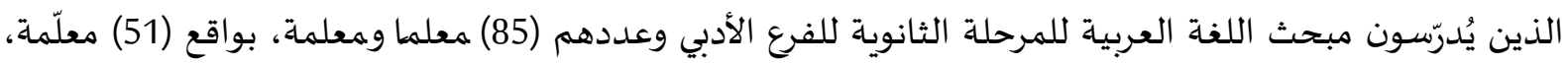

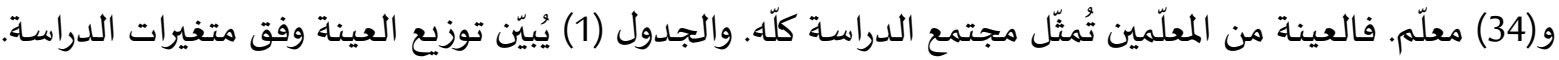

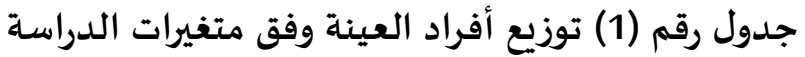

\begin{tabular}{|c|c|c|c|c|}
\hline المجموع & سنوات خبرة طويلة & ستوسطة (5-10) خبرة & سنوات خبرة قصيرة & الجنس الخبرة \\
\hline 34 & 15 & 7 & 12 & معلّم \\
\hline 51 & 14 & 20 & 17 & معلمة \\
\hline 85 & 29 & 27 & 29 & المجموع \\
\hline
\end{tabular}

عينة أداة المقابلة: بلفت عينة أداة المقابلة (16) معلمًا ومعلمة من معلمي المرحلة الثانوية لمبحث اللغة العربية للفرع الأدبي، بواقع (8) معلمات، و(8) معلمين، تمّ اختيارهم باستخدام أسلوب العينة العشوائية البسيطة.

$$
\text { متفيّرات الدراسة }
$$

الخبرة ولها ثلاثة مستويات، هي: أقل من (5) سنوات، ومن (5) سنوات إلى (10) سنوات، أكثر من (10)

بغرض جمْع بيانات الدراسـة، تمّّ بناء الأداتين الآتيتين:

أولاً: مقياس مشكلات تدريس البلاغة، وهي استبانة مكوّنة من (36) عبارة، تمّ وضيع عباراتها في ضوء نيات نتائج

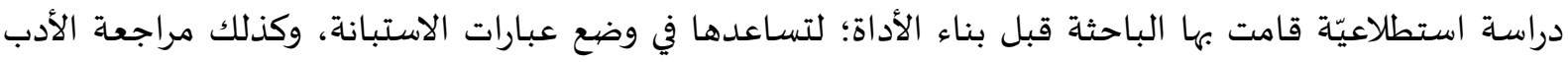

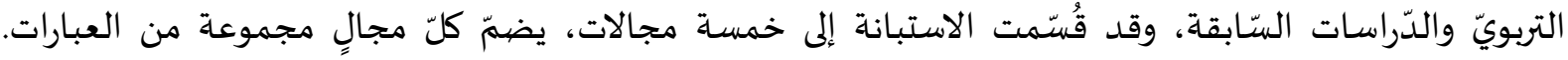

\begin{tabular}{|c|c|c|}
\hline عدد العبارات & المجال & الرقم \\
\hline 8 & المُقرّر الدراسي & 1 \\
\hline 5 & الطالب & 2 \\
\hline 9 & تدريس البلاغـة & 3 \\
\hline 7 & تقويم البلاغة & 4 \\
\hline 7 & المعلم & 5 \\
\hline 36 & المجموع & \\
\hline
\end{tabular}
والجدول (2) يُبيّن ذلك.

جدول رقم (2) توزيع عبارات الاستبانة ضيمن مجالاتها

صدق مقياس الدراسة (استبانة مشكلات تدريس البلاغة):

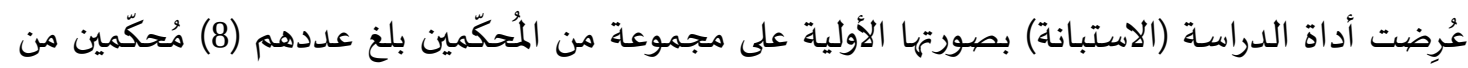

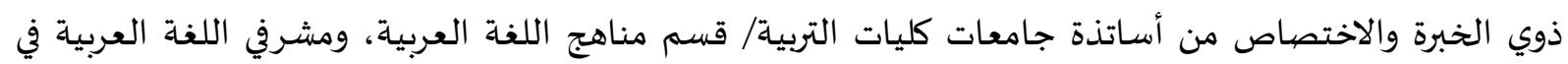




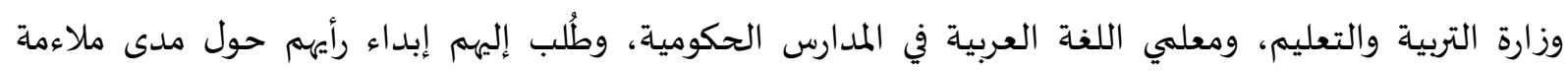

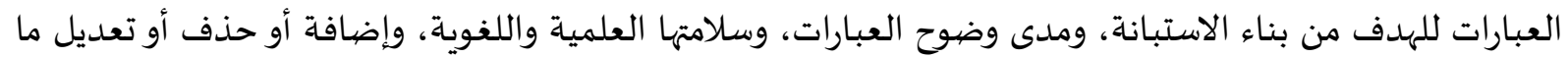

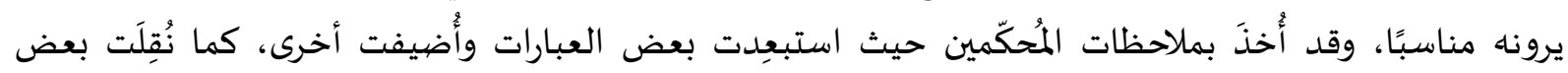
العبارات من مجال إلى مجال آخر.

ثبات مقياس الدراسة (استبانة مشكلات تدريس البلاغة):

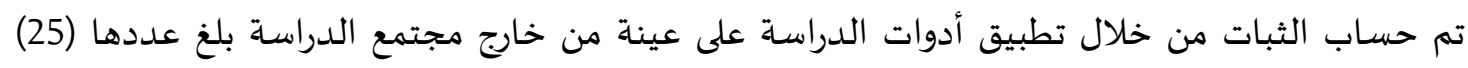

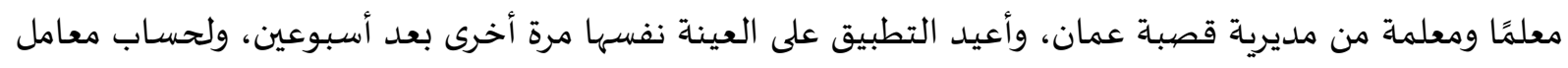

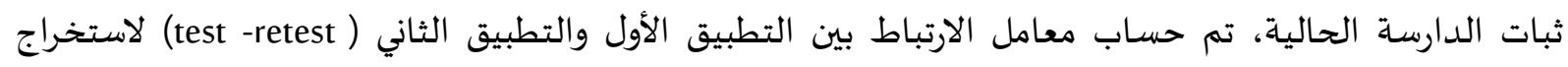

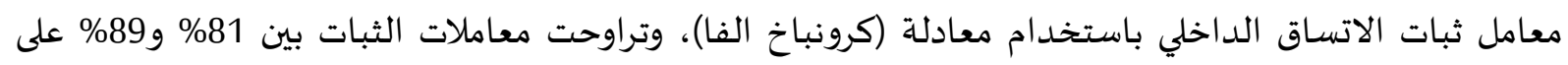

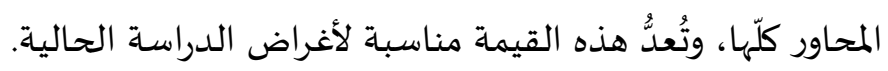

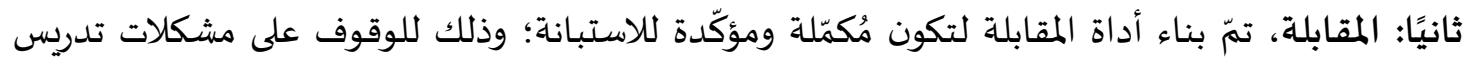

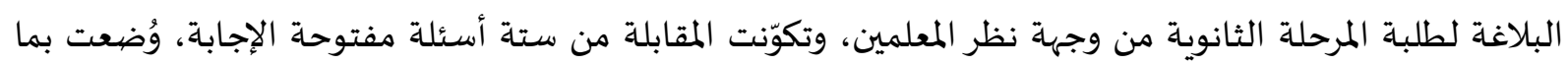
يتناسب مع تدريس البلاغة للمرحلة الثانوية.

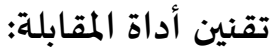
عُرضت أسئلة المقابلة على (9) متخصصين في اللغة، (3) أساتذة جامعيين، و(2) مشرفين تربويين، و(4)

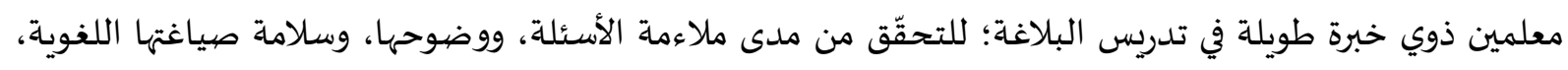

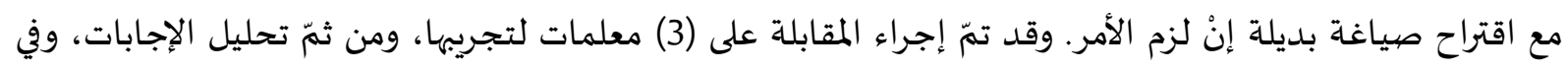

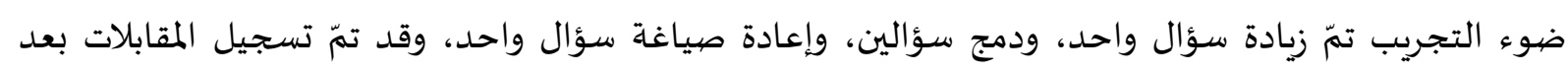
استئذان أفراد العينة.

المعالجات الإحصائية:

استخدمت الباحثة الرزمة الإحصائية (SPSS) للتحليل والإجابة عن أسئلة الدراسة وعلى النحو الآتي:

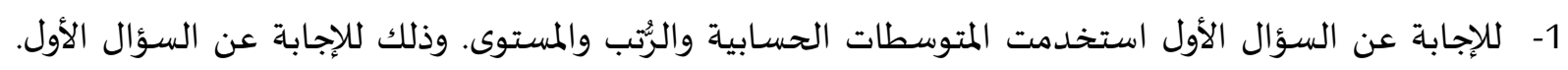

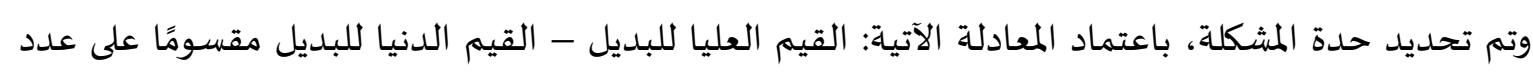

المستويات وهو (3)

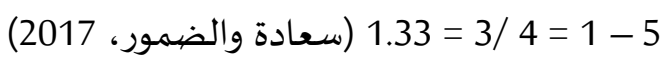

وبذلك يكون عدد المستويات كالآتي:

أ- من 1 - 2.33 مستوى منخفض علد

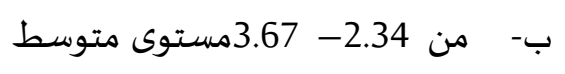

ج- من 3.68- 5 مستوى مرتفع

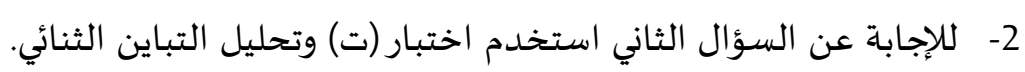

4- عرض النتائج ومناقشتها

أولاً: نتائج استجابات العينة على مقياس الدراسة (استبانة مشكلات تدريس البلاغة) 
الإجابة عن السؤال الأول: ما مشكلات تدريس البلاغة لطلبة المرحلة الثانوية في الأردن من وجهة نظر معلمي

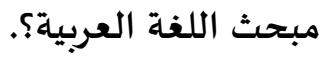

وللإجابة عن هذا السؤال، تمّ استخراج المتوسطات الحسابية والترتيب ومستوى حدّة المشكلة لكل محور

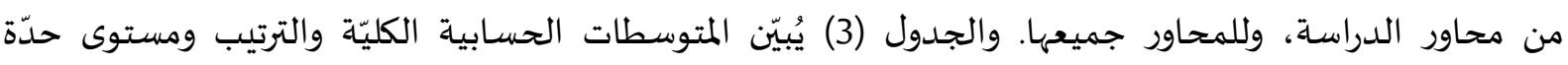

المشكلة للمحاور جميعها.

الجدول (3) المتوسطات الحسابية لكل محور من محاور مشكلات تدريس البلاغة والدرجة الكلية والترتيب وحدّة المشكلة

\begin{tabular}{|c|c|c|c|}
\hline حلدة المشكلة & الترتيب & الدرجة الكلية للمحور & المحور \\
\hline مرتفعة & 1 & 3.72 & المقرر الدراسي \\
\hline متوسطة & 2 & 3.01 & الطالب \\
\hline متوسطة & 3 & 2.67 & تدريس البلاغة \\
\hline متوسطة & 4 & 2.43 & تقويم البلاغة \\
\hline منخفضة & 5 & 2.18 & المعلم \\
\hline متوسطة & \multicolumn{2}{|c|}{2.80} & الدرجة الكلية \\
\hline
\end{tabular}

ويظهر من الجدول (3) أنَّ مشكلات تدريس البلاغة لطلبة المرحلة الثانوية في الأردن جاءت بدرجة متوسطة،

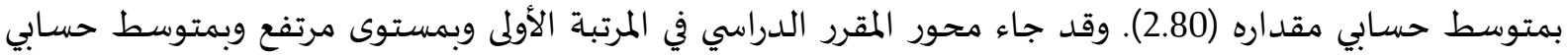

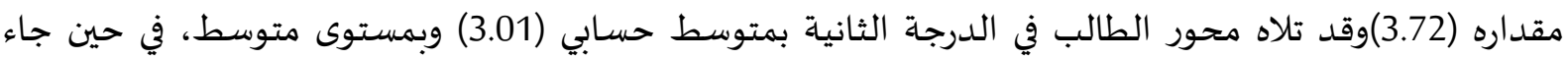
محور تدريس البلاغة في المرتبة الثالثة وبمتوسط حسابي (2.67) وبمستوى متوسط كذلك. تلاه تقويم البلاغة

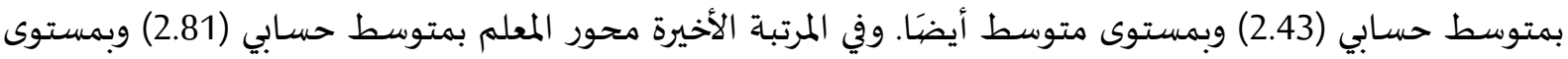

كما تمّ حسـاب المتوسطات الحسابية والترتيب ومستوى حدّة المشكلة للعبارات بكل مجال، وكانت كالآتي:

$$
\text { المحور الأول: المقرر الدراسي }
$$

يُبيّن الجدول: المقرد الدراسئ رقم (4) المتوسطات الحسابية والترتيب ومستوى حدّة المشكلة لكل عبارة من عبارات محور

$$
\text { المقرر الدراسي والبالغ عددها (8) عبارات. }
$$

\begin{tabular}{|c|c|c|c|c|}
\hline 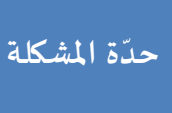 & 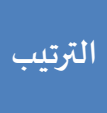 & المتوسطابي & 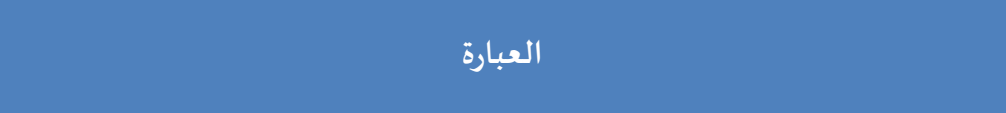 & 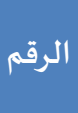 \\
\hline 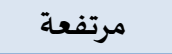 & 1 & 3.96 & الاقتصـار في عرض الموضـوعات البلاغية على الشواهد، وليس من خلال النصوص. & 2 \\
\hline 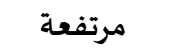 & 2 & 3.93 & قلة الحصص والعلامات المخصصية لمادة البلاغة. & 7 \\
\hline 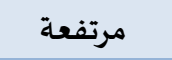 & 3 & 3.92 & تقديم البلاغة في صورة جافة، ومسائل متفرقة. & 4 \\
\hline 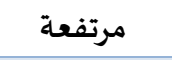 & 4 & 3.81 & تركيز المحتوى على الجانب النظري على حساب الجانب التطبيقي. & 5 \\
\hline 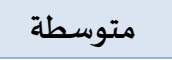 & 5 & 3.57 & الاقتصهار على الشواهد القديمة التي قد يشوبها التعقيد والصعوبة. & 6 \\
\hline متوسطة & 6 & 3.56 & عدم مسايرة المحتوى لمتطلبات العصر. & 3 \\
\hline 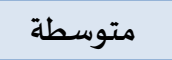 & 7 & 3.55 & عدم تلبية المحتوى لحاجـات الطلبة وخصيائصهيهم النفسية ومـطلبات نموهم. & 8 \\
\hline متوسطة & 8 & 3.48 & بعبد المحتوى عن واقع الطلبة وبيئتهم. & 1 \\
\hline
\end{tabular}

الجدول (4) المتوسطات الحسابية للعبارات والترتيب ومستوى حدّة المشكلة لمحور المقرر الدراسي 


\begin{tabular}{|c|c|c|c|}
\hline حدّة المشكلمة & المتوسط التسبي التيب & العبارة & الرقم \\
\hline مرتفعة & 3.72 & الدرجة الكلية & \\
\hline
\end{tabular}

يُبيّن الجدول (4) أنَّ الدرجة الكلية لعبارات مجال المقرر الدراسي جاءت مرتفعة وبمتوسط حسابي (3.72).

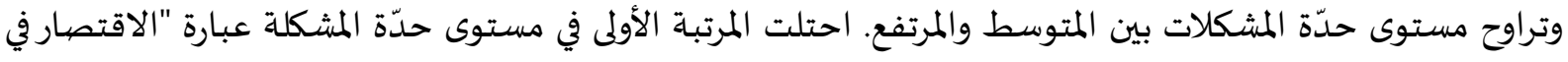
عرض الموضوعات البلاغية على الشواهد، وليس من خلال النصوص" بمتوسط حسابي (3.96)، وفي المرتبة الثانية

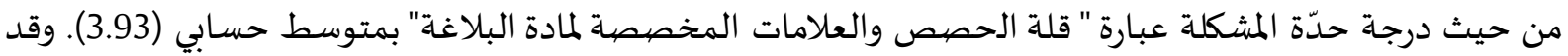
حصلت عبارة " بعدد المحتوى عن واقع الطلبة وبيئتهم. " على أدنى متوسط حسابي، إذ بلغ (3.48). المحور الثاني: الطالب يُبيّن الجدول رقم (5) المتوسطات الحسابية والترتيب ومستوى حدّة المشكلة لكل عبارة من عبارات محور

$$
\text { الطالب والبالغ عددها (5) عبارات. }
$$

الجدول (5) المتوسطات الحسابية للعبارات والترتيب ومستوى حدّة المشكلة لمحور الطالب

\begin{tabular}{|c|c|c|c|c|}
\hline المشكلة - ملية & \multicolumn{2}{|c|}{ المتوسطات } & العبارة & \multirow{2}{*}{2} \\
\hline 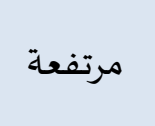 & 1 & 3.78 & نفور الطلبة من الأسساليب والطرق التقليدية التي تُعرض بها موضوعات & \\
\hline 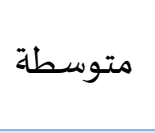 & 2 & 3.29 & الثقافة السائدة الشائعة لدى الطلبة المتمثّلة بكثرة علوم اللغة العربية & 5 \\
\hline 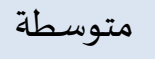 & 3 & 3.28 & تدنّي مستوى امتلاك الطلبة للمهارات اللغوية. & 1 \\
\hline متوسطة & 4 & 2.85 & ضعف القراءة وتدني الفهم القرائي لدى بعض الطلبة مما يُعيق التذوق & 3 \\
\hline منخفضاة & 5 & 1.87 & إهمال أولياءالأممور وتقصيرهم فى متابعة أبنائهم. & 4 \\
\hline 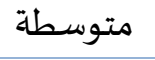 & \multicolumn{2}{|c|}{3.01} & \multicolumn{2}{|l|}{ 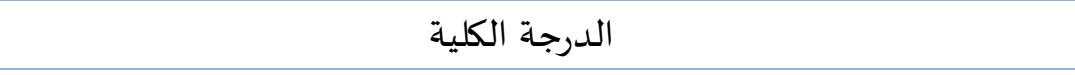 } \\
\hline \multicolumn{5}{|c|}{ 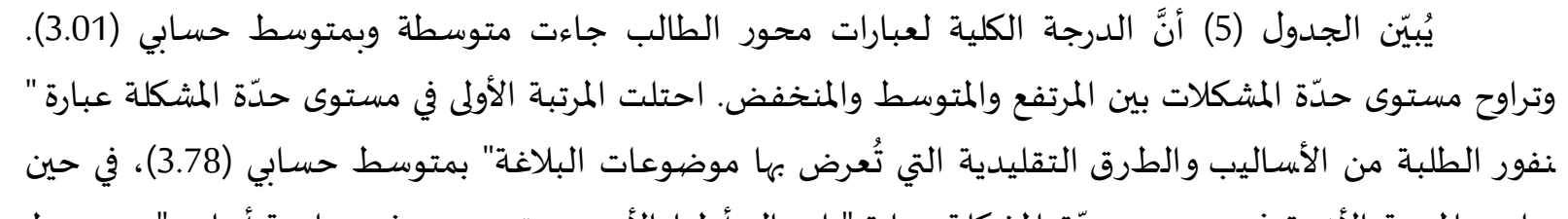 } \\
\hline
\end{tabular}

$$
\text { المحور الثالث- تدريس البلاغة: }
$$

يُبيّن الجدول رقم (6) المتوسطات الحسابية والترتيب ومستوى حدّة المشكلة لكل عبارة من عبارات محور

$$
\text { تدريس البلاغة، والبالغ عددها (9) عبارات. }
$$


الجدول (6) المتوسطات الحسابية للعبارات والترتيب ومستوى حدّة المشكلات لمحور تدريس البلاغة

\begin{tabular}{|c|c|c|c|c|}
\hline مستوى حدّة & الترتيب & المتوسطات الحسابية & 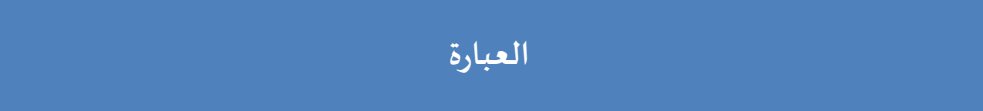 & $\hat{\imath}$ \\
\hline 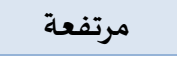 & 1 & 3.75 & قلة استخدام الوسائل التعليمية التي تُيسّر فهم البلاغة. & 8 \\
\hline متوسطة & 2 & 3.66 & توظيف طرق وأساليب قديمة في تدريس البلاغة. & 7 \\
\hline 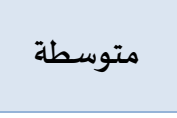 & 3 & 3.35 & 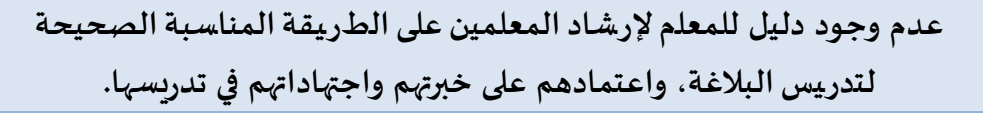 & 9 \\
\hline 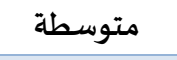 & 4 & 2.51 & تدريس البلاغة من خلال الأمثلة المصنوعة المبتورة بعيدًا عن النص الأدبي. & 5 \\
\hline 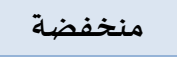 & 5 & 2.36 & المبالغة في التفاصيل والمصططحات والتقسيمات البلاغية. & 4 \\
\hline 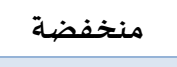 & 6 & 2.17 & إغفال تدريس البلاغة على نحو تكامليّ مع علوم اللغة الأخرى. & 3 \\
\hline منخفضية & 7 & 2.16 & إغفال تدردس الموضوعات البلاغية على نحوٍ تكامليّ. & 2 \\
\hline 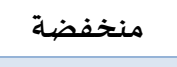 & 8 & 2.04 & شرح دروس البلاغة عن طريق القواعد والمنطق، وإغفال الجانب الذوقي. & 1 \\
\hline 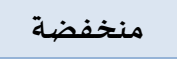 & 9 & 2.03 & عدم الاعتماد على التطبيقات العملية لتدريب الطلبة على تحليل النص وتذوقه. & 6 \\
\hline متوسطة & & .67 & 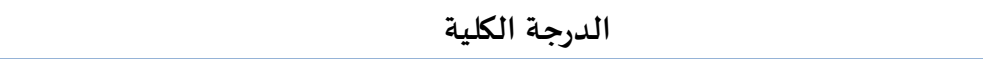 & \\
\hline
\end{tabular}

يُبيّن الجدول (6) أنَّ الدرجة الكلية لعبارات محور تدريس البلاغة جاءت متوسطة وبمتوسط حسابي (2.67). وتراوح مستوى حدّة المشكلات بين المرتفع والمتوسط والمنخفض. احتلت المرتبة الأولى في مستوى حدّة المشكلة

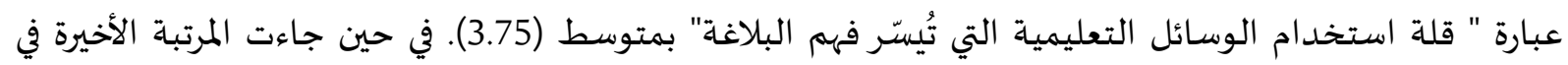

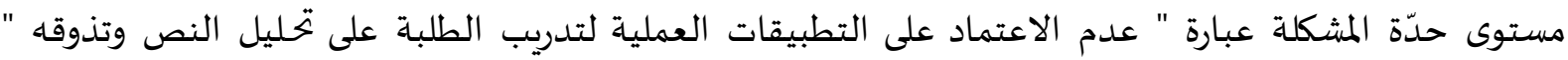
بمتوسط (2.03).

المحور الرابع: تقويم البلاغة: يُبيّن الجدول رقم (7) المتوسطات الحسابية والترتيب ومستوى حدّة المشكلة لكل عبارة من عبارات محور تقويم البلاغة، والبالغ عددها (7) عبارات.

الجدول (7) المتوسطات الحسابية للعبارات والترتيب ومستوى حدّة المشكلات لمحور تقويم البلاغة

\begin{tabular}{|c|c|c|c|c|}
\hline 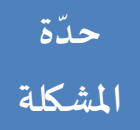 & لتوتيب & المتوسطات & 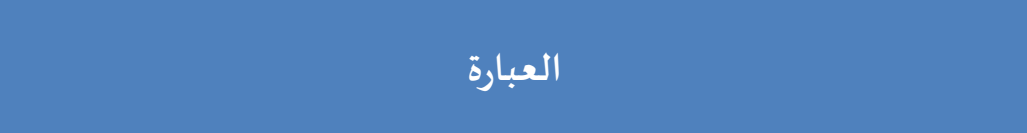 & $\hat{\imath}$ \\
\hline 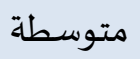 & 1 & 3.13 & التركيز على حفظ البلاغة لا إنتاج البلاغة. & 3 \\
\hline متوسطة & 2 & 2.82 & عدم إسهام التقويم في تطوير الفهم البلاغي لدى الطلبة. & 6 \\
\hline متوسطة & 3 & 2.54 & أسساليب التقويم لا تساهاهم فى تشخيص ججو انب القوة و الضعف لدى الطلبة. & 5 \\
\hline متوسطة & 4 & 2.47 & اقتصار التقويم على الورقة والقلم. & 1 \\
\hline متوسطة & 5 & 2.42 & اقتصار تقويم الورقة والقلم على مهارات التفكير الدنيا. & 2 \\
\hline 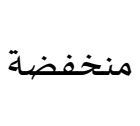 & 6 & 1.98 & أسـاليب التقويم لا تحقق التوازن فى قياس المعارف والاتجاهات والمهارات & 7 \\
\hline 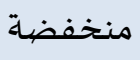 & 7 & 1.63 & إهمال تقويم التذوّق وقياسـه. & 4 \\
\hline متوسطة & \multicolumn{2}{|c|}{2.43} & \multicolumn{2}{|l|}{ الدرجة الكلية } \\
\hline
\end{tabular}

يُبيّن الجدول (7) أنَّ الدرجة الكلية لعبارات محور تقويم البلاغة جاءت متوسطة وبمتوسط حسابي (2.43). وتراوح مستوى حدّة المشكلات بين المتوسط والمنخفض. احتلت المرتبة الأولى في مستوى حدّة المشكلة عبارة " التركيز 
على حفظ البلاغة لا إنتاج البلاغة " بمتوسط حسابي (3.13). في حين جاءت المرتبة الأخيرة في مستوى حدّة المشكلة عبارة " إهمال تقويم التذوّق وقياسه " بمتوسط حسابلي (1.36).

\section{المحور الخامس: المعلم}

يُبيّن الجدول رقم (8) المتوسطات الحسابية والترتيب ومستوى حدّة المشكلة لكل عبارة من عبارات محور

$$
\text { المعلم، والبالغ عددها (7) عبارات. }
$$

الجدول (8) المتوسطات الحسابية للعبارات والترتيب ومستوى حدّة المشكلات لمحور المعلم

\begin{tabular}{|c|c|c|c|c|}
\hline 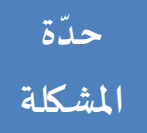 & لترتيب & المتوسطا. & 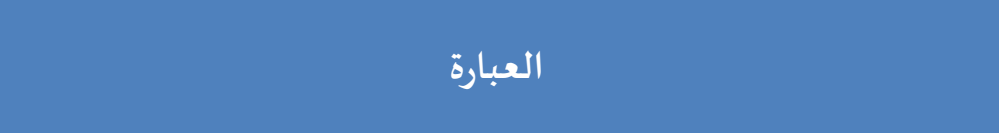 & $\hat{\imath}$ \\
\hline 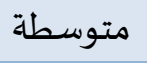 & 1 & 3.59 & الإخفاق في الربط بين النظرية والتطبيق. & 6 \\
\hline 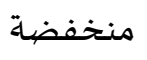 & 2 & 2.25 & عدم معرفة المعلم بأساليب تدريس البلاغة وطرق تقويمها. & 7 \\
\hline 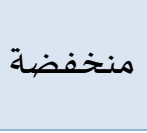 & 3 & 2.16 & التدريس الآليّ من قبل بعض المعلمين دون الرجوع إلى النتاجات المحورية & 2 \\
\hline 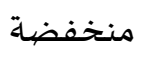 & 4 & 2.01 & إغفال مواهب الطلبة وعدم الاهتمام بها. & 5 \\
\hline منخفضاة & 5 & 1.87 & انعدام الابتكاروالتشويق في طرق العرض. & 3 \\
\hline 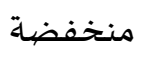 & 6 & 1.81 & عدم تمكّن المعلم من مهارات التذوّق الأدبي والبلاغي. & 4 \\
\hline 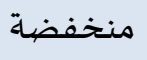 & 7 & 1.62 & التركيز على المعلم وإغفال الطالب كمحور للعملية التعليمية التعلّمية. & 1 \\
\hline 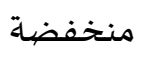 & \multicolumn{2}{|c|}{2.18} & \multicolumn{2}{|l|}{ 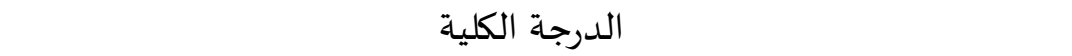 } \\
\hline
\end{tabular}

يُبيّن الجدول (8) أن الدرجة الكلية لعبارات محور المعلم جاءت منخفضية وبمتوسط حسابي (2.18). وتراوح

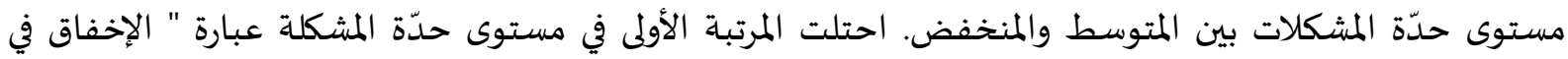

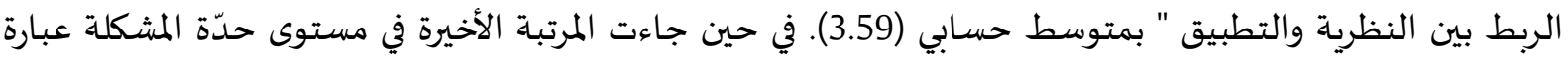

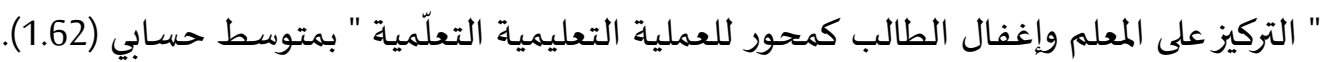

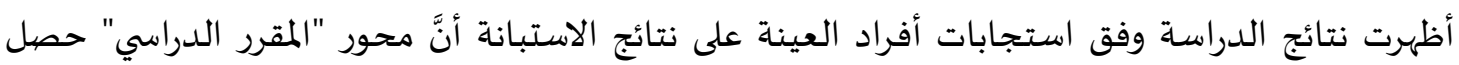

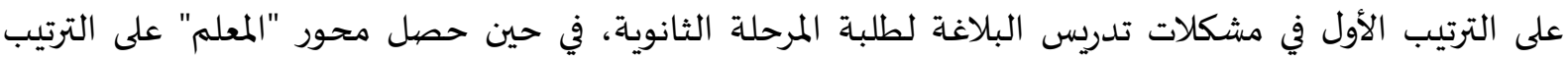
الأخير، ويمكن أن يُعزى حصول محور المقرر الدراسي على المرتبة الأولى في حدة مشكلات تدريس البلاغة إلى الجمود

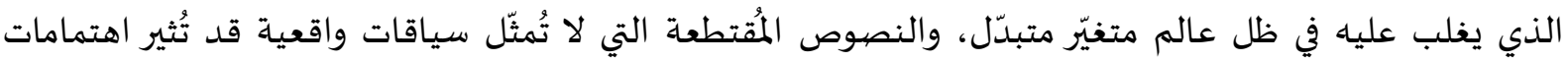

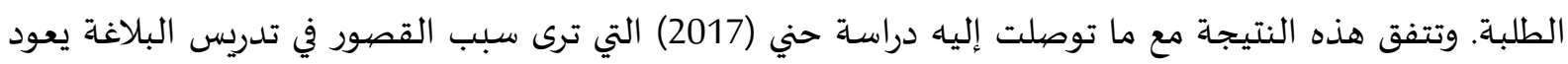
إلى التقيّد بالقوالب الجاهزة، ودراسة بيوش (2016) التي كشفت أنَّ صعوبة المادة إحدى المشئ المشكلات.

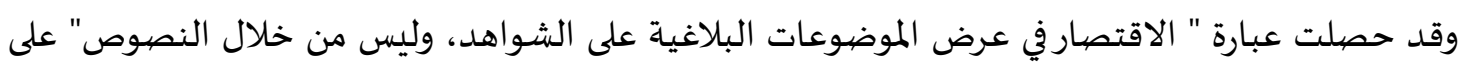

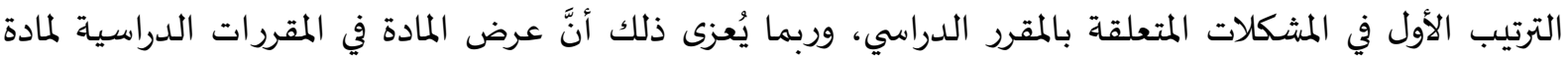

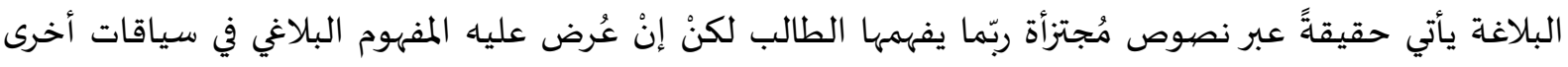

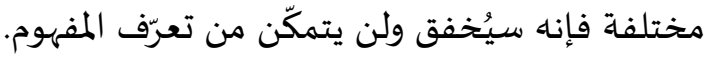
ويمكن أن نعزو حصول محور "الطالب" على الترتيب الثاني في مستوى حدة مشكون منكلات تدريس البلاغة إلى أنَّ

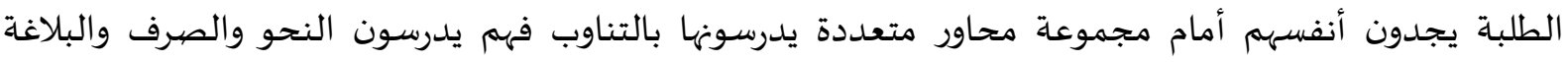
والنقد والقضايا الأدبية، إلى جانب مقرر اللغة العربية. ربما يشعرون بانفصال المحاور وكثرتها مما يُشعرهم بالملل. 
وتتفق هذه النتيجة مع ما توصيّلت إليه دراسة بيوش (2016) إذ كشفت أن 65\% من أفراد العينة أفادوا أن المادة

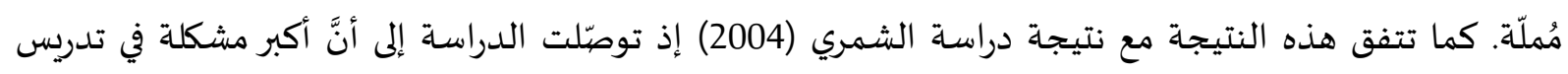
البلاغة مرتبطة بالطالب؛ لعدم قناعتهم بانتفاعهم منها.

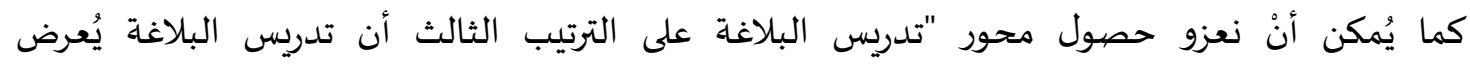

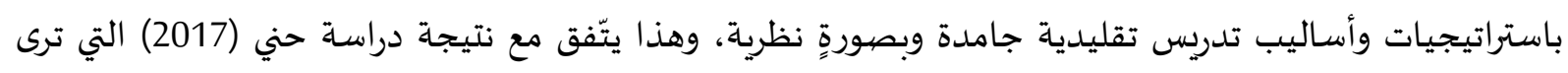

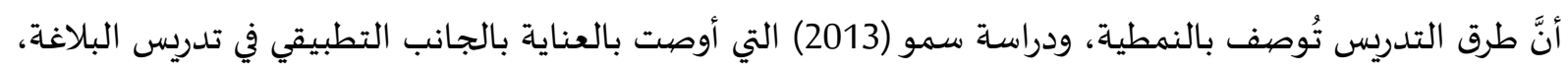

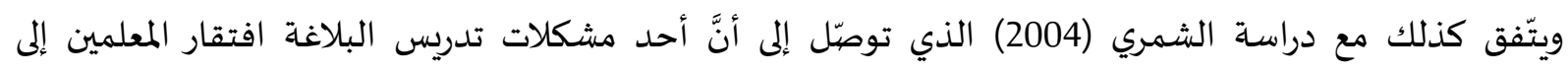
أساليب تدريس البلاغة. ويمكن أنْ نعزو حصول محور المعلم على الترتيب الخامس والأخير في مستوى حدة مشكلات تدريس البلاغة

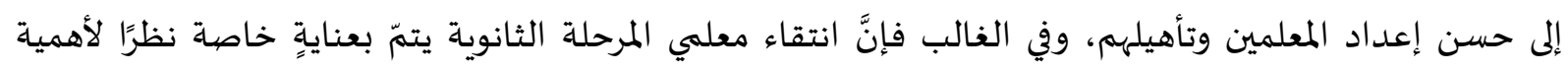

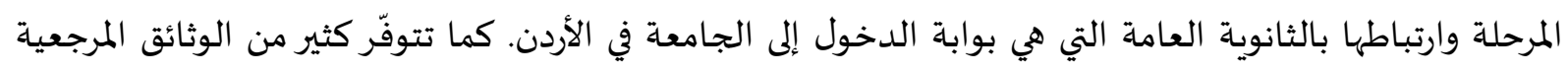

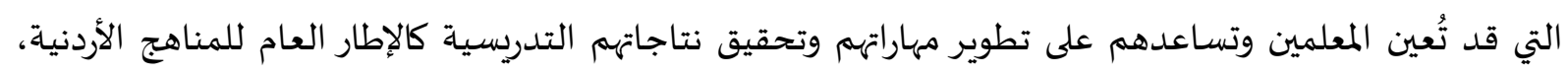

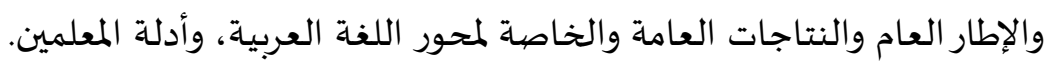

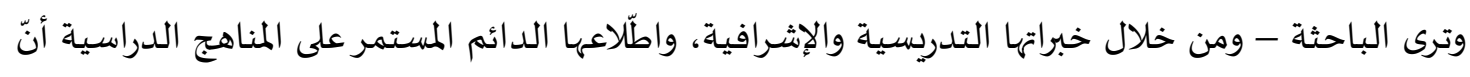

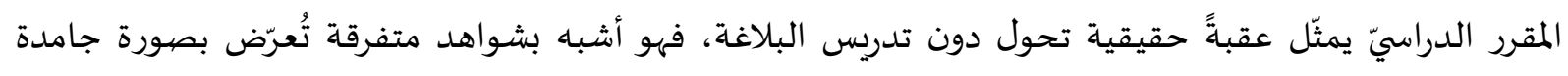

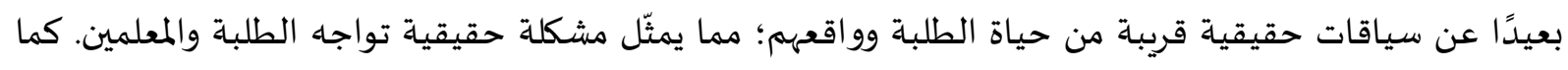

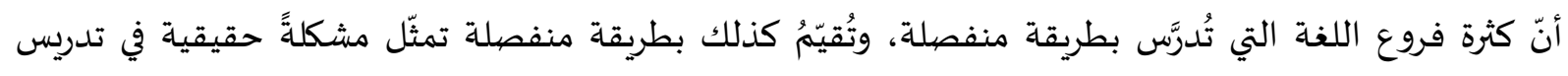

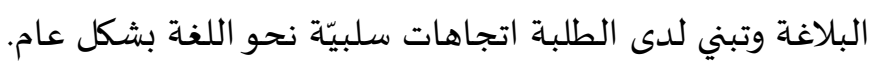

ثانيًا- نتائج استجابات العينة على أسئلة المقابلة:

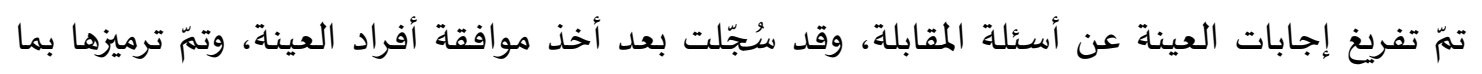

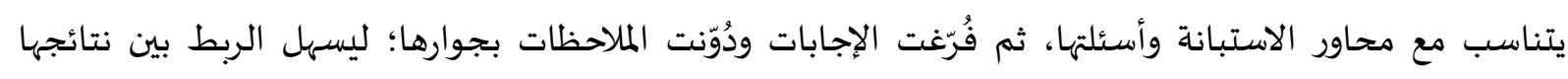
ونتائج الاستبانة. وقد أكّدت إجابات العينة عن أسئلة المقابلة ما توصيّلت إليه نتائج الاستبانة، فاحتلّ محور " المقرر

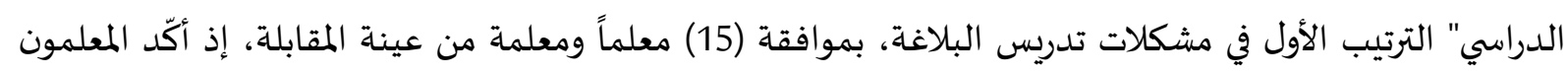

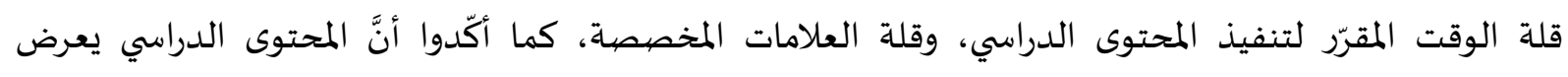

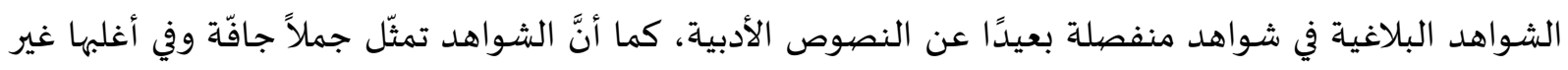

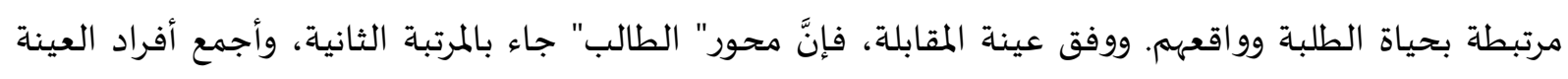

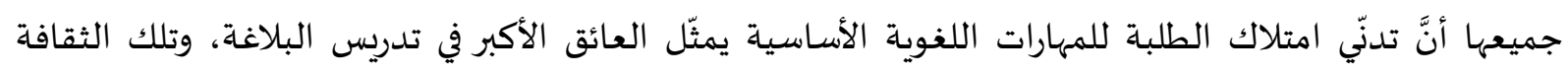

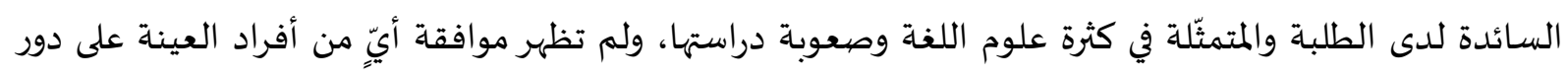

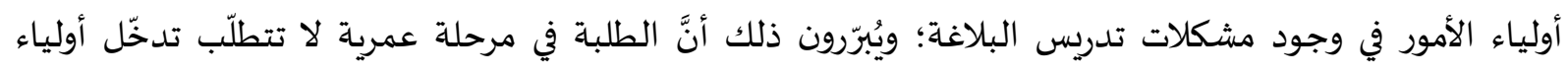
الأمور في تدريس أبنائهم.

وقد اختلف أفراد العينة في استجاباتهم على محاور " تدريس البلاغة " و" تقويم البلاغة" إذ رأي (6) من

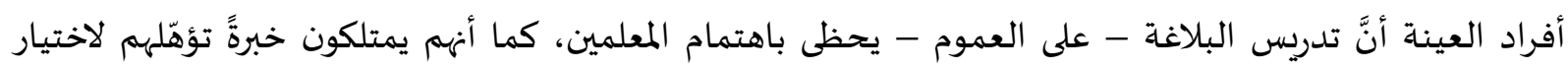

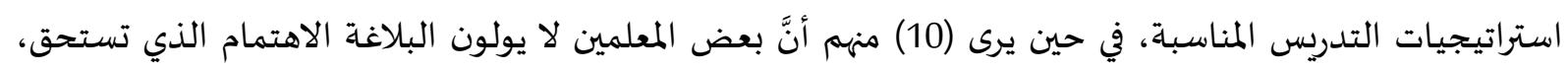


كما أههم يوظّفون استراتيجيات غير مشوّقة. وفيما يتعلّق بمحور " تقويم البلاغة " فقد اتفق (12) من أفراد العينة

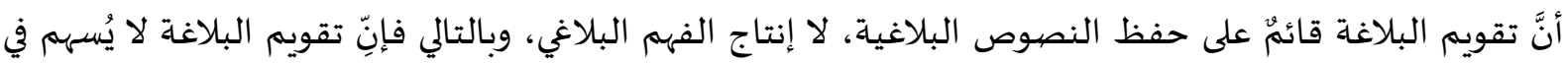

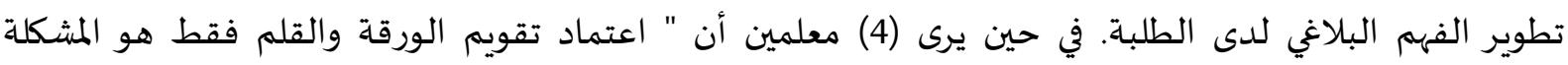
الحقيقية في تقويم البلاغة.

ونجد أنَّ استجابات أفراد العينة في كلتا الأداتين اتفقت على ترتيب واحد لمستوى مشكلات تدريس البلاغة، واختلفت قليلاً في العبارات -ضمن المحور الواحد - التي حصلت على أعلى ترتيب. وترى الباحثة أنّ هذه الاختلافات التئل

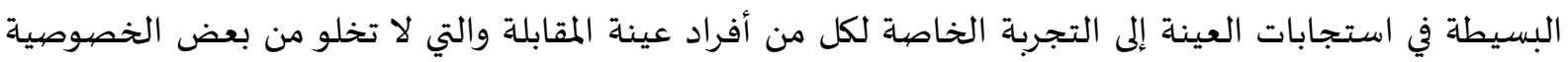
والانعكاسات الشخصية لها.

الإجابة عن السؤال الثاني: هل تختلف مشكلات تدريس البلاغة للمرحلة الثانوية باختلاف الجنس وسنوات

\section{الخبرة والتفاعل بينهما؟}

ولإجابة عن هذا السؤال تمّ استخراج المتوسطات والانحراف المعياري لاستجابات أفراد العينة من معلمين

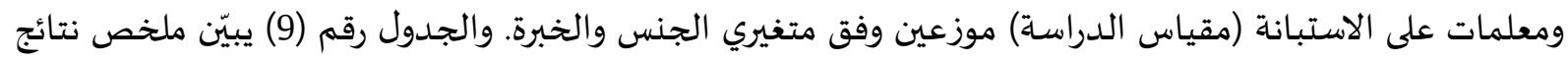
اختلاف مشكلات تدريس البلاغة باختلاف الجنس والخبرة.

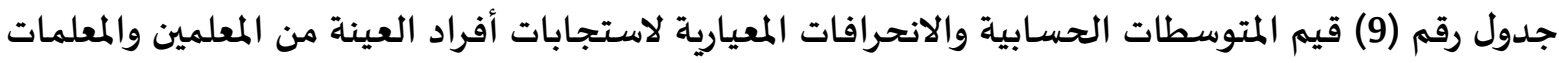

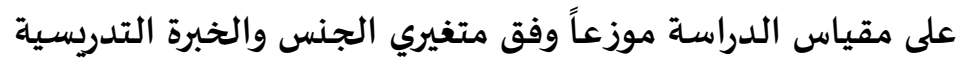

\begin{tabular}{|c|c|c|c|c|c|}
\hline المجموع & خبرة تدريسية طويلة & خبرة تدريسية & خبرة تدريسية قصيرة & \multicolumn{2}{|c|}{ الجنس } \\
\hline 68.4 & 70.6 & 67 & 67.8 & المتوسط الحسابي & \multirow{3}{*}{ معلم } \\
\hline 3.4 & 3.3 & 5.2 & 1.9 & الانحراف المعياري & \\
\hline 34 & 15 & 7 & 12 & العدد العد & \\
\hline 67.6 & 67.5 & 67.6 & 67.8 & المتوسط الحسـابي & \multirow{3}{*}{ معلمة } \\
\hline 3.1 & 3.7 & 2.5 & 3.1 & الانحراف المعياري & \\
\hline 51 & 14 & 20 & 17 & العدد & \\
\hline 68 & 69 & 67.3 & 67.8 & المتوسط الحسابي & \multirow{3}{*}{ المجموع } \\
\hline 3.2 & 3.5 & 3.8 & 2.5 & الانحراف المعياري & \\
\hline 85 & 29 & 27 & 29 & العدد & \\
\hline
\end{tabular}

يُظهر الجدول رقم (9) أنَّ متوسط المعلمين متقارب جداً مع متوسط المعلمات، حيث بلغت متوسطات

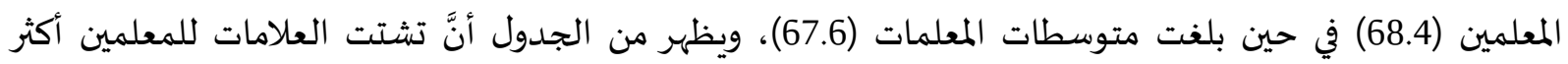

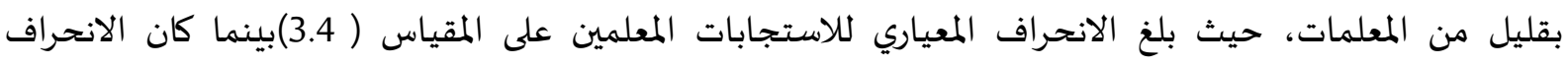

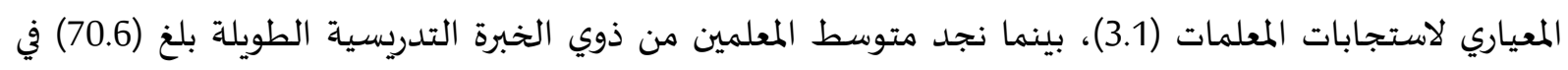

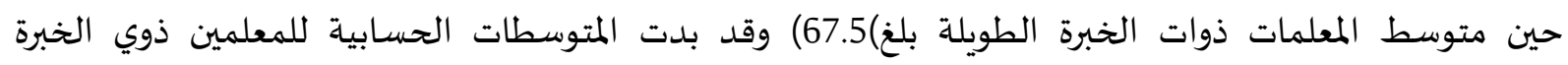
المتوسطة والقليلة تتقارب جداً مع متوسطات المعلمات ذوات الخبرة المتوسطة والقليلة. 
نتبيّن مما سبق أنَّ هناك فروقًا ظاهرية بين المتوسطات الحسابية للمجموعات، وللكشف عن الدلالة

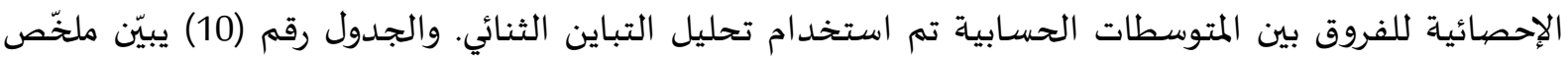
هذه النتائج. الجدول رقم (10) نتائج تحليل التباين الثنائي لاختبار فروق المتوسطات لمشكلات تدريس البلاغة وفقاً لمتغيري الجنس، الخبرة التدريسية، التفاعل بينهما.

\begin{tabular}{|c|c|c|c|c|c|}
\hline مستوى الدلالة & $\mathbf{F}$ & متوسطات & درجات الحرية & مجموع المربعات & مصهدر التباين \\
\hline .520 & .432 & 4.867 & 1 & 4.867 & الجنس \\
\hline .384 & .984 & 11.314 & 2 & 22.627 & الخبرة التدريسية \\
\hline \multirow[t]{3}{*}{.414} & .905 & 10.404 & 2 & 20.807 & التفاعل بين الجنس والخبرة \\
\hline & & 11.494 & 34 & 390.804 & 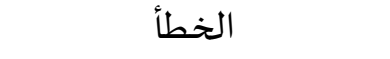 \\
\hline & & & 39 & 452.400 & المجموع المعدّل (الكلي) \\
\hline
\end{tabular}

يُظهر الجدول أن قيمة "ف" تساوي (0.432) وبمستوى دلالة (0.520)وهي أكبر من مستوى الدلالة

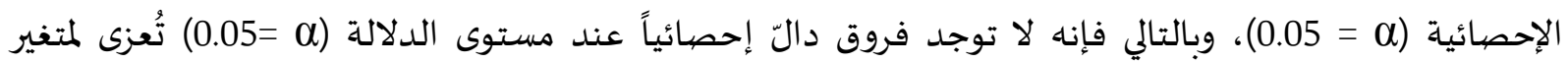

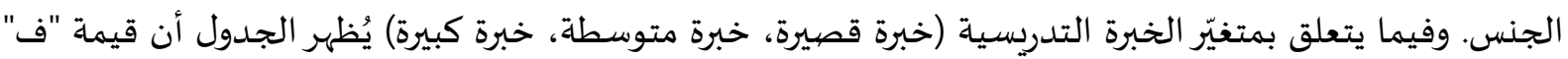

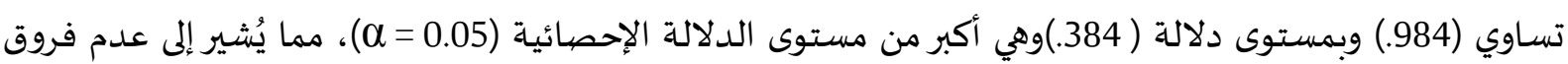

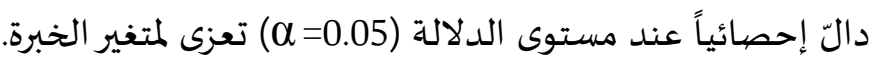
ويظهر فيما يتعلّق بوجود فروق تُعزى إلى التفاعل بين متغير الجنس (معلم، معلمة) ومتغير الخبرة التدريسية الخبرة

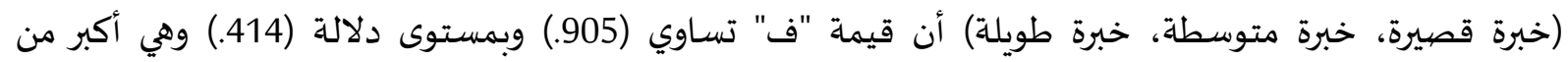

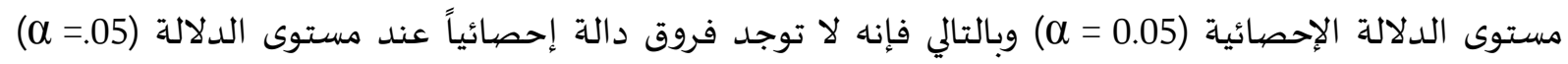
تُعزى للتفاعل بين متغيري الجنس (معلم، معلمة) ومتفير الخبرة التدريسية (قليلة، متوسطة، كبيرة).

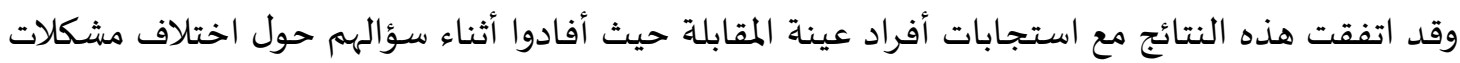

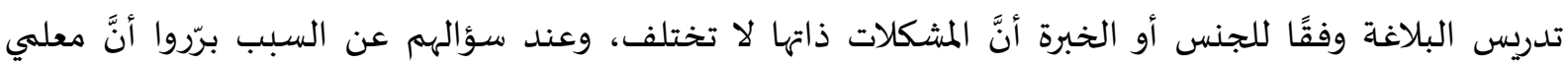
المرحلة الثانوية من الذكور أو الإناث وبمختلف خبراتهم يتعرّضون للدورات التهبه التدريبية ذاتها، كما أنهم يمتلكون الفهم ذاته لتدريس البلاغة بما ينسجم مع عدد الحصص المقرر ونصيب مهارة البلاغة من العلامات الذي تُقترّه وزارة التربية

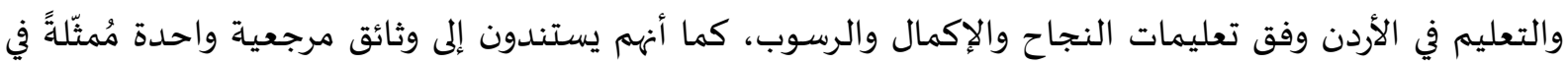

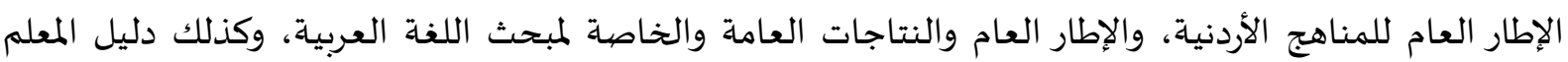
الذي يُحدّد إجراءات تدريس البلاغة ويقترح استراتيجيات للتدريس والتقويم المناسبتين.

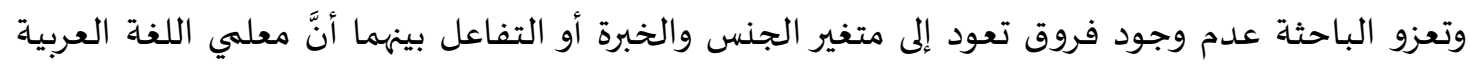

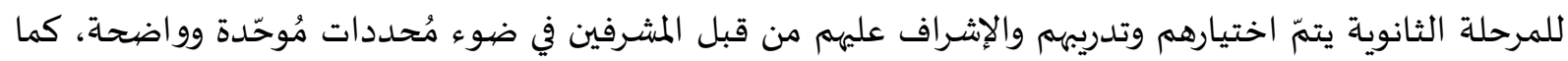

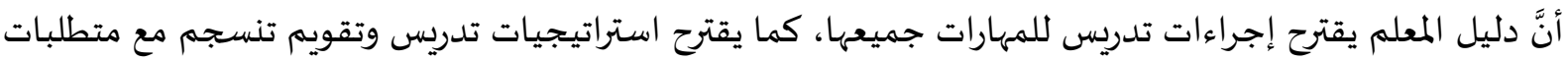

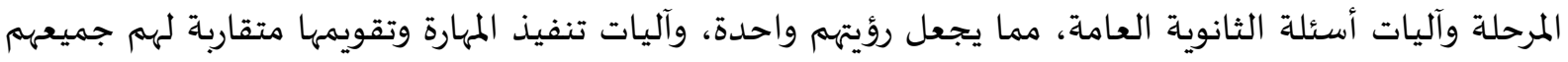

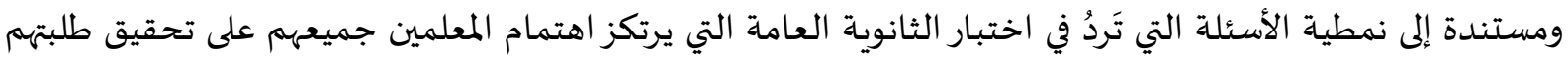

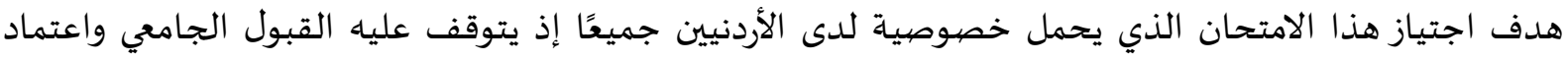

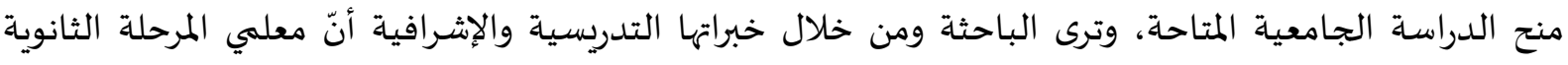


ذكورًا وإناثًا، ومهما بلغت خبراتهم التدريسية يجمعهم وحدة الهدف المُتمثّل في مساعدة الطلبة ورفح نسبة نجاحهم

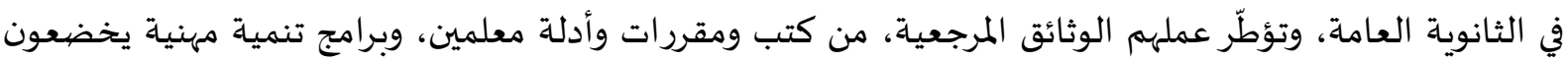
لها. وبالتالي لم تظهر فروق دالّة تعود لمتغيري الجنس أو الخبرة أو التفاعل بينهما.

التوصيات والمُقترَحات.

$$
\text { في ضوء النّائج التي توصيّلت إلهها هذه الدّراسة، تُوصي الباحثة وتقترح الآتي: }
$$

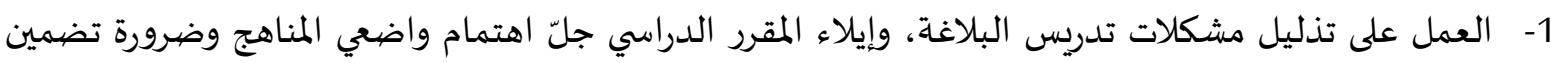
محتوى تطبيقيّ للمقرر الدراسي ضمن سياقات أدبيّة وبما ينسجم مع واقع الطلبة تلدية واهتماماتهم.

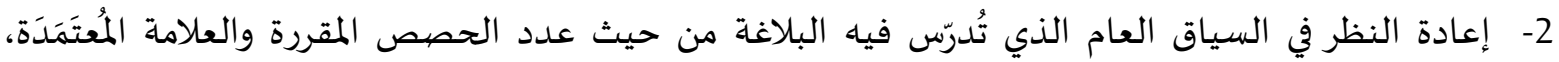
وإعطاء محور البلاغة أهميّةً أكبر. 3- إجراء المزيد من الدّراسات في تدريس البلاغة والمشكلات التي تعترضها بمحاور مختلفة ومراحل دراسية مختلفة. قائمة المراجع.

$$
\text { - - ابن منظور (2005). لسكان العرب، ط4، دار صهادر، بيروت. }
$$

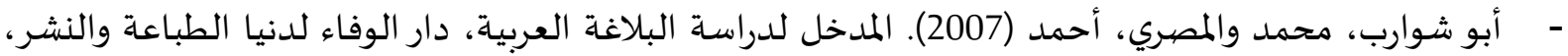

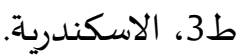

- - الأغا، إحسان والاستاذ، محمود (2003)، تصميم البحث التربوي، ط (3)، مطبعة الرنتيسي، غزة. - جلو، باسلة موسى (2005). علم البلاغة نشأته وتطوره وأهدافه وتعريفه وعلوماه. ط1

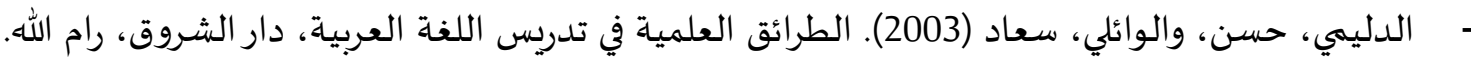

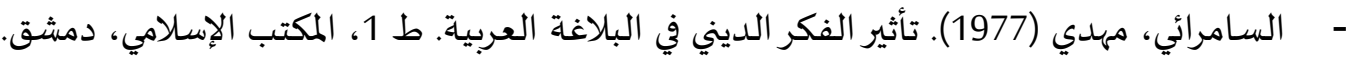

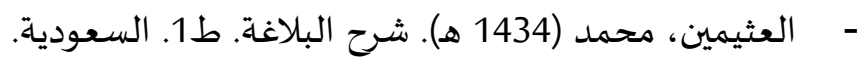

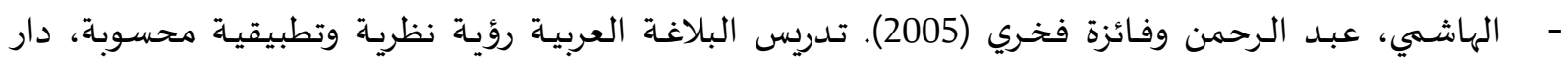
المسيرة، عمان. وز وزارة التربية والتعليم (2013). الإطار العام والنتاجات العامة والخاصة لمبحث اللغة العربية، عمان، الأردن. - وزارة التربية والتعليم (2020). أسس النجاح والإكمال والرسوب 2019- 2020 ب- الرسائل والأطاريح والدوريات: - أبو جاموس، عبد الكريم؛ والعبد، محمود (2007)، مدى امتلاك طلبة المرحلة الثانوية في الأردن للمفاهيم البلاغية وقدرتها على توظيفها في التعبير الكتابي، مجلة العوم الإنسانية، الجزائر، 28 (2).

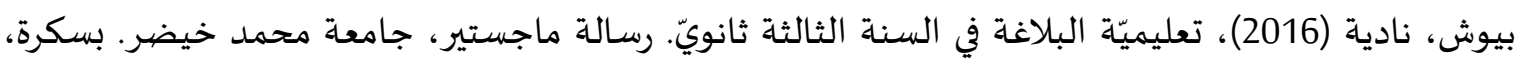
الجزائر. جني، عبد اللطيف (2017)، طرق تعليمية علوم البلاغة العربية وأثرها في المهارات اللغوية للمتعلم بين الواقع والمأمول، جسور المعرفة، 2(7)، 14-24. 
راجع، أحمد (2017). تعليمية نشاط البلاغة في المرحلة الثانوية ـ دراسة وصفية ميدانية . أطروحة دكتوراه. جامعة قاصدي مرباح. ورقلة. الجزائر - سعادة، جودت والضمور، سامي (2017)، مشكلات تدريس مادة اللغة الإنجليزية لطلبة الأول الثانوي في منطقة

الكرك التعليمية من وجهة نظر المعلمين. مجلة الزرقاء للدراسات والبحوث الإنسانية 17 (1). سمو، دارين (2013)، آراء عينة من مدرسي مادة اللغة العربية حول مشكلات تدريس البلاغة في المرحلة الثانوية

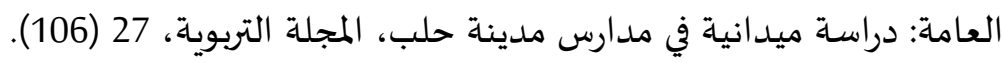

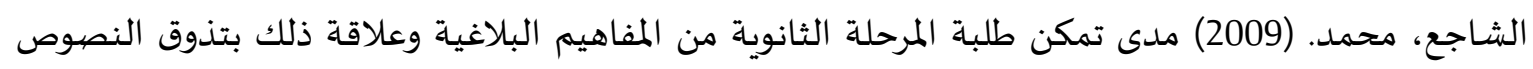

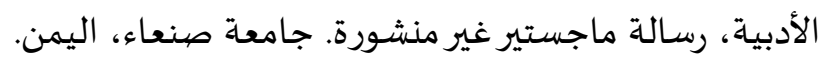

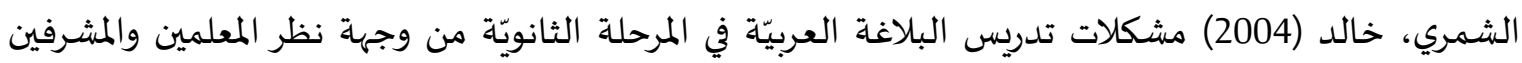
التربويين، رسالة ماجستير. جامعة الملك سعود. السعوديّة. عايش، آمنة (2003)، صبعوبات تعليم البلاغة لدى طلبة قسم اللغة العربية فى الجامعة الإسلامية بعزية وبرنامج مقترح لعلاجها، رسالة ماجستير، غزة. 